Published in final edited form as:

Gastroenterology. 2020 January ; 158(2): 368-388. doi:10.1053/j.gastro.2019.06.047.

\title{
Chemoprevention of Colorectal Cancer
}

\author{
Bryson W. Katona ${ }^{1}$, Jennifer M. Weiss ${ }^{2}$ \\ ${ }^{1}$ Division of Gastroenterology, Department of Medicine, University of Pennsylvania Perelman \\ School of Medicine, Philadelphia, PA \\ ${ }^{2}$ Division of Gastroenterology and Hepatology, Department of Medicine, University of Wisconsin \\ School of Medicine and Public Health, Madison, WI
}

\begin{abstract}
Although colorectal cancer (CRC) screening has reduced the incidence and mortality from CRC, chemoprevention strategies have potential to further reduce CRC incidence and mortality. Chemoprevention agents might be used for average-risk as well as high-risk groups, and to prevent colorectal cancer recurrence after therapy. CRC chemoprevention agents that have been studied include aspirin, non-aspirin non-steroidal anti-inflammatory drugs, statins, agents that target metabolic pathways, and vitamins and minerals. We review the prospect of chemoprevention of $\mathrm{CRC}$, results from preclinical and human studies, challenges, and future directions.
\end{abstract}

\section{Keywords}

Colorectal cancer; Adenoma; Chemoprevention

Colorectal cancer (CRC) is a significant global health burden and is the second and third most commonly diagnosed cancer worldwide in women and men respectively, with more than 140,000 new cases diagnosed in the United States (US) in 2019. ${ }^{1,2}$ Developing more efficacious treatments and improving screening have led to reductions in CRC incidence and mortality, although the burden remains significant and additional strategies for CRC prevention are needed. ${ }^{3-8}$

One strategy to decrease CRC risk that has been extensively studied over the past several decades is chemoprevention. The term chemoprevention was first coined in $1976,{ }^{9}$ and refers to the use of a synthetic or natural substance to decrease the risk of developing cancer, delay the time of cancer onset, or to reverse the carcinogenesis process (Figure 1). However, finding an effective chemoprevention agent for cancer is not an easy task-only a small number of cancer chemoprevention agents have been approved by the Food and Drug Administration. ${ }^{10}$ There are many important caveats to consider when evaluating potential

Correspondence: Jennifer M. Weiss MD, MS, Division of Gastroenterology and Hepatology, University of Wisconsin School of Medicine and Public Health, 800 University Bay Dr., Suite 210-35, Madison, WI 53705-2281, Phone: (608) 263-1995; jmw@medicine.wisc.edu.

Publisher's Disclaimer: This is a PDF file of an unedited manuscript that has been accepted for publication. As a service to our customers we are providing this early version of the manuscript. The manuscript will undergo copyediting, typesetting, and review of the resulting proof before it is published in its final form. Please note that during the production process errors may be discovered which could affect the content, and all legal disclaimers that apply to the journal pertain. 
chemoprevention agents. Given the length of time that chemoprevention must be administered to prevent cancer, especially in average risk populations, it is important for these agents to be well tolerated with minimal side effects (Figure 1). The agents must also be available at low cost and easy to administer, with a convenient dosing schedule. These are high baseline requirements that must be met before clinical trials can even begin to evaluate efficacy.

Chemoprevention studies for cancer are challenging; they are often long in duration and require a large population and substantial financial investment. For trials of agents that might prevent CRC, a key aspect of study design is to determine whether the endpoint will be precancerous lesions or CRC. Most CRCs develop from adenomas, ${ }^{11}$ adenomas increase CRC risk, ${ }^{12}$ and adenoma removal decreases CRC risk. ${ }^{13,} 14$ Therefore, it is a logical extension that results from studies showing that agents can prevent adenoma formation would lead to the conclusion that they would reduce CRC. Studying the effects of chemoprevention agents on adenoma development is certainly easier and requires less time and fewer patients than studying effects on CRC development. Another potential premalignancy endpoint is aberrant crypt foci (ACF)—precursors of adenomas and CRC initially discovered in mice and validated in studies of humans. ${ }^{15-17}$ However ACFs have not been widely used in most chemoprevention trials given their variable rates of detection and uncertainties regarding their relationship to CRC risk. ${ }^{18,19}$ Another challenge for chemoprevention studies with a CRC endpoint is that participants may modify their CRC risk by undergoing screening - it would be unethical to withhold CRC screening from 1 group of participants, given its clear benefits. ${ }^{3-7}$ There are therefore multiple challenges associated with CRC chemoprevention studies. Despite these challenges, numerous chemopreventive agents (Table 1) have been studied. We review findings from these studies.

\section{Aspirin}

The agent with the strongest data to support its CRC chemoprevention effects is aspirin. Acetylsalicylic acid, officially named aspirin in $1899,{ }^{20}$ irreversibly inhibits cyclooxygenase 1 (COX1) and cyclooxygenase 2 (COX2). ${ }^{21}$ Although there is debate over aspirin's exact mechanism of chemoprevention, it inhibits several CRC-related pathways, including prostaglandin synthesis, platelet activation, Wnt signaling to beta catenin, and inflammation.

${ }^{21}$ Studies of aspirin prevention of death from all cancers are inconclusive, reporting significant ${ }^{22}$ and non-significant ${ }^{23}$ reductions in death. For CRC specifically, the first report of aspirin's association with decreased CRC risk was a case-control study in 1988, which showed fewer cases of CRC in individuals taking aspirin-containing medications. ${ }^{24}$ Studies in the 1990s showed that aspirin reduced chemically induced tumor development in rodents and tumor development in genetically engineered mice with polyposis. ${ }^{25-27}$ Since then, findings from extensive preclinical and clinical studies on aspirin led the US Preventative Services Task Force (USPSTF) to recommend aspirin for prevention of cardiovascular disease (CVD) and CRC - this was the first time a chemopreventive agent was endorsed for a non-high risk population. ${ }^{23,} 28,29$ However, this recommendation was only made for adults 50-59 years old, with a $10 \%$ or more 10 -year risk of CVD, who are expected to live more than 10 years, without an increased risk of bleeding. ${ }^{23,28,29}$ For patients $60-69$ years old, 
aspirin use should be individualized. Given the ongoing accumulation of evidence on aspirin, these recommendations might change. ${ }^{28}$

Although aspirin chemoprevention studies with CRC as an endpoint have produced mixed results, they have mostly found evidence for an association with decreased risk of CRC (Table 2). A case-control study in Denmark found that individuals who continuously filled low-dose aspirin prescriptions for 5 or more years had a decreased risk of CRC (odds ratio, 0.73; 95\% CI, 0.54-0.99)..$^{30}$ The Health Professionals Follow-up Study associated aspirin use with decreased risk of CRC in men (relative risk 0.79; 95\% CI, 0.69-0.90) after at least 6 years of use, with increasing benefits with higher doses of aspirin. ${ }^{31,32}$ However, the association between aspirin use and decreased risk of CRC disappeared 4 years after aspirin cessation. The Nurses' Health Study found similar results, but the association of aspirin use with CRC risk was only significant after 20 years. ${ }^{33}$ Combining data from the Health Professionals Follow-up Study and Nurses' Health Study demonstrated a reduced risk of $\mathrm{CRC}$ from aspirin with as little as $0.5-1.5$ tablets of aspirin per week ${ }^{34}$ Furthermore, among the more than 140,000 participants in the Cancer Prevention Study II Nutrition Cohort, those taking at least $325 \mathrm{mg}$ of aspirin for 5 or more years had decreased CRC risk (relative risk $0.68 ; 95 \%$ CI, 0.52-0.90). ${ }^{35}$

Randomized placebo-controlled trials of aspirin have primarily been secondary analyses of trials with primary CVD endpoints. The large Women's Health Study found no reduction in CRC risk during the 10-year active trial. ${ }^{36}$ However a significant reduction in aspirin users was noted after extended post-trial follow-up (hazard ratio, 0.80; 95\% CI, 0.67-0.97). ${ }^{37}$ Although neither the UK transient ischemic attack (UK-TIA) aspirin trial nor the Swedish aspirin low dose trial (SALT) found that aspirin reduced risk of CRC, pooling of the data with the British Doctors Aspirin Trial and the Thrombosis Prevention Trial showed aspirin use decreased CRC incidence (hazard ratio, 0.76; 95\% CI, 0.60-0.96) and mortality (hazard ratio, $0.65 ; 95 \% \mathrm{CI}, 0.48-0.88) .{ }^{38,39}$ Furthermore, the association between aspirin use and decreased risk of CRC was more pronounced with 5 or more years of aspirin therapy and after 10 years following aspirin initiation. ${ }^{38}$ Additional meta-analyses also showed that aspirin decreases the incidence and mortality from CRC. ${ }^{23,} 40$ Other studies have failed to show an association such as the Physician's Health Study, which showed no significant decrease in CRC risk with aspirin use after 12 years of follow up. ${ }^{41,42}$ Additionally, the Aspirin in Reducing Events in the Elderly (ASPREE) trial, surprisingly, found increased allcause and cancer-related mortality and increased risk of CRC with aspirin use (hazard ratio, 1.77; 95\% CI, 1.02-3.06).$^{43}$ Studies with a colonic adenoma endpoint also show mixed results (Table 2). The Aspirin Folate Polyp Prevention Study showed low-dose, but not highdose, aspirin decreased risk of adenoma (relative risk, $0.81 ; 95 \%$ CI, 0.69-0.96) and advanced adenoma/carcinoma (relative risk, $0.59 ; 95 \%$ CI, 0.38-0.92) ${ }^{44}$ The Association pour la Prévention par I'Aspirine du Cancer Colorectal (APACC) trial found individuals with prior colonic adenomas taking lysine acetylsalicylate had decreased risk of having 3 or more adenomas (relative risk $0.3 ; 95 \% \mathrm{CI}, 0.10-0.89$ ) or an adenoma of $5 \mathrm{~mm}$ or larger (relative risk $0.44 ; 95 \%$ CI, $0.24-0.82$ ) after 1 year, ${ }^{45}$ but no decrease in risk after 4 years. ${ }^{46}$ In a Japanese cohort with endoscopically resected colonic adenomas or adenocarcinoma, aspirin reduced the risk of developing a colonic adenoma or adenocarcinoma by $40 \%$ (95\% CI, 0.36-0.98) ${ }^{47}$ Interestingly, subgroup analyses found more prominent risk reduction in 
current nonsmokers, whereas aspirin paradoxically increased CRC risk in smokers. Smoking also negated the protective effects of aspirin in a US-based population. ${ }^{48}$

In the Colorectal Adenoma Prevention Study from the cooperative trials group Cancer and Leukemia Group B (CALGB), individuals with prior CRC randomly assigned to groups that received aspirin had a lower risk of developing colonic adenomas (relative risk, $0.65 ; 95 \%$ CI, 0.46-0.91) and developed adenomas at later times (relative risk, 0.64; 95\% CI, $0.43-$ 0.94) ${ }^{49}$ Furthermore, the United Kingdom Colorectal Adenoma Prevention (UKCAP) study showed that aspirin decreased risk of adenoma (relative risk, 0.79; 95\% CI, 0.63-0.99) and advanced adenoma (relative risk, $0.63 ; 95 \%$ CI, 0.43-0.91). ${ }^{50}$ Similar results were observed in other studies ${ }^{32,51}$ and are supported by a meta-analysis. ${ }^{52}$ Data from the Nurses' Health Study showed the greatest reduction in adenoma risk for participants who took 14 or more tablets of aspirin per week (relative risk, $0.49 ; 95 \% \mathrm{CI}, 0.36-0.65$ ). ${ }^{53}$

Aspirin chemoprevention of CRC has also been studied in high-risk groups. The Colorectal Adenoma/Carcinoma Prevention Programme 1 (CAPP1) study found that aspirin did not decrease colonic polyp burden in familial adenomatous polyposis (FAP), but 1 year or more of aspirin use decreased the largest polyp size. ${ }^{54}$ The CAPP2 study, which has been the only randomized placebo-controlled trial of aspirin with CRC as the primary endpoint, investigated use of $600 \mathrm{mg}$ of aspirin daily in individuals with Lynch syndrome. Although the initial post-intervention analysis showed no significant differences, ${ }^{55}$ later analysis showed that for participants of at least 2 years, aspirin significantly reduced CRC risk (hazard ratio, $0.41 ; 95 \% \mathrm{CI}, 0.19-0.86) .{ }^{56}$ Aspirin also reduced CRC risk in patients with Lynch syndrome in the Colon Cancer Family Registry. ${ }^{57}$ A meta-analysis showed that, in individuals with a prior history of CRC, aspirin decreased CRC mortality (hazard ratio, 0.76; 95\% CI, 0.66-0.88).$^{58}$ Interestingly, among aspirin users, those with colorectal tumors with mutations in PIK3CA had longer survival times than patients whose tumors did not have PIK3CA mutations. ${ }^{59}$

One concern with long-term aspirin use is the side effect of gastrointestinal bleeding. Participants in the ASPREE trial who took $100 \mathrm{mg}$ of aspirin daily had an increased risk of major hemorrhage (hazard ratio, 1.38; 95\% CI, 1.18-1.62). ${ }^{60}$ Similarly participants in the Use of Aspirin to Reduce Risk of Initial Vascular Events in Patients at Moderate Risk of Cardiovascular Disease (ARRIVE) trial who took $100 \mathrm{mg}$ of aspirin daily had more bleeding events $(0.97 \%$ vs $0.46 \%$; hazard ratio, $2.11 ; 95 \%$ CI, $1.36-3.28)$, but no difference in rate of fatal bleeding. ${ }^{61}$ Aspirin users in the Women's Health Study had a slightly increased risk of gastrointestinal bleeding and peptic ulcer disease, but no difference in deaths related to gastrointestinal bleeding, ${ }^{37}$ whereas other studies found no significant increase in any serious adverse event, including gastrointestinal bleeding. ${ }^{4}$

The Aspirin for Dukes C and High Risk Dukes B Colorectal Cancers (ASCOLT) study has examined the effects of aspirin in adjuvant treatment for individuals with previously treated CRC. ${ }^{62}$ Similarly, the Dutch trial A Trial of Aspirin on Recurrence and Survival in Colon Cancer Patients (ASPIRIN) ${ }^{63}$ and the ADD-Aspirin trial ${ }^{64}$ are each investigating whether aspirin can prevent recurrence of CRC in patients with non-metastatic CRC who underwent treatment. The CAPP3 study is exploring lower doses (100 mg and $300 \mathrm{mg}$ ) of aspirin for 
chemoprevention of CRC in patients with Lynch syndrome. ${ }^{65}$ Furthermore, the Aspirin Intervention for the Reduction of Colorectal Cancer Risk (ASPIRED) study of individuals with prior colonic adenomas aims to clarify the mechanism of aspirin chemoprevention through biosample collection. ${ }^{66}$ Given the surprising increased cancer-related mortality observed in the ASPREE trial, the ASPREE-XL study will provide longitudinal follow-up data to clarify these findings. Clarification of the mechanisms of aspirin chemoprevention is also important, because a study demonstrated that inhibition of platelet aggregation alone with clopidogrel reduced CRC risk, similar to aspirin. ${ }^{67}$ Additional important questions include better defining what subgroups would benefit most, because aspirin reduced risk for colorectal tumors that express high levels of $\mathrm{COX} 2,{ }^{68}$ whereas other studies found that aspirin effects on CRC risk varied based on 2 single nucleotide polymorphisms. ${ }^{69}$ Studies of aspirin use to augment CRC screening found aspirin use to be as effective as screening with the fecal occult blood test or flexible sigmoidoscopy in reducing CRC mortality, although these findings require validation. ${ }^{70}$

Studies of aspirin have indicated its chemopreventive effects for CRC. Aspirin likely leads to a modest reduction in adenoma and CRC risk, although only after prolonged, continuous use and accompanied by an increased risk of bleeding. Currently, aspirin is recommended for CRC chemoprevention in select individuals with increased CVD risk, as well as individuals with Lynch syndrome. However, there are many questions that remain, including the dose and frequency of aspirin needed, the target population, and the magnitude of the risk reduction with aspirin use in individuals undergoing screening.

\section{Non-aspirin NSAIDs}

Non-aspirin NSAIDs inhibit COX1 and COX2, except unlike aspirin this inhibition is competitive. ${ }^{71}$ In the 1970s it was recognized that colorectal tumors express high levels of prostaglandin $\mathrm{E}_{2}\left(\mathrm{PGE}_{2}\right){ }^{72,} 73 \mathrm{PGE}_{2}$ synthesis requires COX2, so NA-NSAIDs might prevent development of CRC. Studies in rodent models found NA-NSAIDs to prevent enteric tumorigenesis to some degree. ${ }^{74-76}$ In case-control studies in humans, NA-NSAID use was associated with decreased risk of CRC. A case-control study from Denmark found individuals who filled NA-NSAID prescriptions to have a reduced risk of CRC (odds ratio, $0.57 ; 95 \%$ CI, 0.44-0.74), especially those with prescriptions for long-term, high-dose NSAIDs. ${ }^{30}$ Women in Wisconsin who used NA-NSAIDs at least twice per week for 1 year or more were less likely to receive a diagnosis of CRC (odds ratio, 0.43; 95\% CI, 0.200.89). ${ }^{77}$ Case-control studies also found that use of a broad range of NSAIDs, including selective and non-selective COX2 inhibitors, reduced risk of $\mathrm{CRC}^{78}$ and adenoma ${ }^{51}$. A recent meta-analysis of 23 studies demonstrated that NA-NSAIDs decreased risk of CRC (odds ratio, $0.74 ; 95 \% \mathrm{CI}, 0.67-0.81$ ), and subgroup analysis found the largest protective effects in women, in patients taking higher doses of NSAIDs, in patients of white race, and against distal colorectal tumors. ${ }^{79}$

In patients with FAP, 9 months treatment with the NA-NSAID sulindac significantly reduced colon polyp number and diameter (Table 3) ${ }^{80} \mathrm{~A}$ similar reduction in polyp number were observed in the residual rectum of patients with FAP after longer term follow up. ${ }^{81}$ However, sulindac did not prevent the initial development of adenomas in patients who had not yet 
developed the colonic polyposis phenotype. ${ }^{82}$ Sulindac also significantly decreased the formation of $\mathrm{ACF}$, and in individuals who had colon polyps removed, this drug significantly decreased risk for subsequent colonic adenomas. ${ }^{83}$ The chemopreventive effects of other non-selective NA-NSAIDs have been studied in high-risk populations. A study of individuals with Lynch syndrome from the Colon Cancer Family Registry showed that taking ibuprofen for 1 month or more was associated with decreased risk of CRC ${ }^{57}$ A phase IB study of patients with Lynch syndrome is underway to examine the preventative effects of naproxen. ${ }^{84}$

Given the gastrointestinal bleeding risks associated with non-selective NA-NSAIDs, ${ }^{85}$ likely related to COX1 inhibition, selective COX2 inhibitors might be safer chemopreventive agents. The Prevention of Colorectal Sporadic Adenomatous Polyps trial found that celecoxib reduced adenoma detection after 3 years (relative risk, 0.64; 95\% CI, 0.56-0.75).

86 The Adenoma Prevention with Celecoxib (APC) trial also found that celecoxib decreased adenoma detection after 3 and 5 years. ${ }^{8788}$ Interestingly in this cohort, polyps that expressed $\mathrm{COX} 2$ or did not express 15-prostaglandin dehydrogenase, which degrades $\mathrm{PGE}_{2}$, had a reduced risk of adenoma formation. ${ }^{89}$ High-dose celecoxib was also effective in patients with FAP, decreasing colorectal polyp burden by $31 \%$ after 6 months. ${ }^{90}$ Rofecoxib also reduced adenoma formation, ${ }^{91,92}$ but it was withdrawn from the market by the Food and Drug Administration due to increased cardiovascular risk. ${ }^{93}$ Similar safety concerns were raised in the APC trial, in which celecoxib use was associated with an increased risk of cardiovascular events. ${ }^{94}$ Ultimately, a review by the USPSTF stated that although NANSAIDs, including selective COX2 inhibitors, reduced the risk of colonic adenomas and $\mathrm{CRC}$, these agents were associated with significant cardiovascular events and increased risk of gastrointestinal side effects. ${ }^{95}$ Due to these concerns, NA-NSAIDs have not been widely accepted as potential CRC chemopreventive agents except for in high-risk populations such as individuals with FAP.

\section{Metabolic Agents}

\section{Metformin}

Type 2 diabetes is an independent risk factor for CRC leading to interest in anti-diabetic medications as potential CRC chemoprevention agents. ${ }^{96}$ Metformin is a biguanide compound often used first-line in type 2 diabetes. Proposed anti-neoplastic properties include activation of adenosine monophosphate-activated protein kinase (AMPK), which inhibits the mammalian target of rapamycin (mTOR) pathway to prevent cell proliferation. 97-99 Metformin might also slow tumor growth by inhibiting cyclin D1 expression or Rb phosphorylation. ${ }^{100}$ Metformin reduced polyp formation in a genetic mouse model of FAP ${ }^{101}$ and reduced ACF in mice given a chemical carcinogen. ${ }^{99}$ However, results from epidemiology and clinical studies vary. Epidemiology studies showed a decreased risk of CRC with metformin use, ${ }^{102-108}$ no association, ${ }^{109-111}$ or increased risk. ${ }^{112,} 113$ Observational studies are subject to multiple time-related biases (immortal time bias, time window bias, and time-lag bias). A study of 47,531 patients with type 2 diabetes that used methods to reduce time-related biases showed decreased risk of CRC with metformin use for 5 or more years in men (hazard ratio, 0.65 ; $95 \%$ CI, $0.45-0.94$ ), but not in women. ${ }^{114}$ Many 
epidemiology studies have not accounted for potential cancer-modifying effects of concomitant anti-diabetic medications. Restricting a larger meta-analysis to studies adjusting for concomitant anti-diabetic medication use showed a more modest (11\%) reduction in CRC incidence among metformin users (adjusted odds ratio, 0.88; 95\% CI, 0.78-0.99). ${ }^{115}$

Metformin has also been evaluated for its chemopreventive effect on adenomas. A metaanalysis of 10 studies found an inverse association between metformin use and colorectal adenoma risk (odds ratio, 0.76 ; $95 \% \mathrm{CI}, 0.63-0.92$ ); the protective effect remained after adjusting for confounding variables. Subgroup analyses were performed in 3 groups: those with diabetes, those with a history of CRC or adenomas, and those with no history of adenomas regardless of diabetes status. ${ }^{116}$ Metformin reduced risk of adenomas in patients with diabetes (odds ratio, $0.75 ; 95 \% \mathrm{CI}, 0.62-0.91$ ) with a trend toward lower risk of adenomas in metformin users with a history of CRC/adenomas.

The first randomized controlled trial (RCT) to examine the chemoprevention effect of lowdose metformin ( $250 \mathrm{mg} /$ day) on metachronous colorectal polyps or adenomas showed that over 1 year, the incidence of total polyps (relative risk, 0.67; 95\% CI, 0.47-0.97), as well as adenomas alone (relative risk, $0.60 ; 95 \% \mathrm{CI}, 0.40-0.92$ ), were significantly lower with metformin use. ${ }^{117}$ Limitations of this study included the small sample size, short length of follow up, and generalizability due to the high-risk population (approximately $70 \%$ with a history of advanced adenoma or multiple adenomas). This RCT was included in a recent meta-analysis that found reductions in risk of adenoma (odds ratio, 0.75 ; 95\% CI, 0.590.97 ) and colorectal tumors (odds ratio, $0.87 ; 95 \% \mathrm{CI}, 0.70-0.87$ ) in patients with type 2 diabetes taking metformin. ${ }^{118}$ Overall, the data support the use of metformin as a first-line oral agent in diabetic patients at high risk for CRC. For the general population, definitive RCTs are needed to better establish the chemopreventive effect of metformin, which should include populations at average risk and high risk for CRC and adenomas.

\section{Statins}

Statins are 3-hydroxy-3-methylglutaryl-coenzyme A (HMG-CoA) reductase inhibitors commonly prescribed for their lipid-lowering properties. Approximately $25 \%$ of Americans older than 40 years take a statin for CVD prevention. ${ }^{119}$ Statins competitively inhibit HMGCoA reductase, the rate-limiting enzyme of the mevalonate pathway; ${ }^{120}$ disruptions of this pathway in neoplastic cells might reduce tumor initiation, growth, or metastasis. ${ }^{121}$ Statins inhibited proliferation of human CRC cell lines and promoted apoptosis. ${ }^{122,}{ }^{123}$ In mice with carcinogen-induced or genetically induced colorectal neoplasia, statins reduced colorectal tumor development alone ${ }^{124}$ or in combination with NSAIDs. ${ }^{125,126}$

Similar to studies of metformin, however, results from epidemiologic and clinical studies of statins and colorectal neoplasia have produced inconsistent results. These include observational studies and secondary outcomes from RCTs examining effects of statins on cardiovascular events. A well-publicized observational study from northern Israel found that 5 or more years of self-reported statin use was associated with a $45 \%$ reduction in CRC risk (odds ratio, 0.55; 95\% CI, 0.40-0.74). ${ }^{127}$ Interestingly, a subsequent study using the same population showed that specific polymorphisms in the HMG-CoA reductase gene modify the protective association between statins and CRC risk. ${ }^{128}$ A study of a large cohort of US 
veterans also showed a similar reduction in CRC risk with statin use (hazard ratio, 0.65; 95\% CI, 0.55-0.78). ${ }^{129}$ In contrast, several meta-analyses of case-control and cohort studies have shown smaller risk reductions (risk estimates $0.86-0.91)^{130-132}$ or no association. 133, 134 The inconsistent results from observational studies could result from healthier behaviors among statin users compared with non-users, residual confounding from over the counter NSAID use that is difficult to capture with administrative data, different hydrophilicity of specific statins, ${ }^{135,} 136$ differential effects on colon vs rectal cancers, ${ }^{127,} 137$ or issues with selection bias and immortal-time bias. ${ }^{138}$

Analyses of data from RCTs evaluating statins and cardiovascular events have provided opportunities to examine effects of statin use on overall and subtype-specific cancer risk. Multiple meta-analyses have found no association between statin use and CRC risk, 130, 131, 133 including a meta-analysis of 27 RCTs published by the Cholesterol Treatment Trialists' Collaboration. ${ }^{139}$ One of the main criticisms of conclusions made from these data is the short duration of follow up (often less than 5 years). ${ }^{140}$ However, 2 RCTs with longer follow-up times (the West of Scotland Coronary Prevention Study ${ }^{141}$ and the Heart Protection Study ${ }^{142}$ found no difference in CRC incidence after 10 and 11 years follow up, respectively. In addition, data on cancer incidence and mortality are not systematically collected in RCTs of cardiovascular effects, leading to possible ascertainment bias, and many of these trials are conducted in high-risk populations with competing risks. ${ }^{140}$

A few studies have evaluated the effects of statin use on incidence of colorectal adenomas and yielded mixed results. A study of 2626 veterans with colon adenomas removed at index colonoscopy found a $49 \%$ reduction in recurrence of adenomas and a $29 \%$ reduction in risk of advanced adenomas in subjects who took statins continuously for 3-5 years. ${ }^{143}$ In contrast, secondary analyses of multiple adenoma chemoprevention trials found no association between statin use and recurrent, multiple, or advanced adenomas. ${ }^{144}$ Analyses of data from the APC trial found a 39\% increase in risk of adenomas with statin use for 3 or more years. ${ }^{145}$ So, we cannot unequivocally confirm the significant association between statin use and decreased risk of CRC or adenoma. Well-designed studies are needed to determine the effects of long-term statin use, necessary dosage, ideal combinations with other chemopreventive agents, and subgroups most likely to benefit from statin therapy. ${ }^{140}$

\section{Long-chain omega-3 polyunsaturated fatty acid supplements}

Long-chain omega-3 polyunsaturated fatty acids, which reduce inflammation, are predominantly found in dietary sources such as dark fish. ${ }^{146}$ Eicosapentanoic acid (EPA) and docosahexanoic acid (DHA) are used in treatment for coronary heart disease and hypertriglyceridemia, with good safety profiles. ${ }^{147}$ Studies of rodents and CRC cell lines demonstrated the antineoplastic effects of EPA and DHA, including anti-proliferative, apoptotic, and anti-angiogenic properties. ${ }^{147-149}$ A proof of concept RCT of EPA ( 2 g/day for 6 months) for patients with FAP found significant reductions in number and size of rectal adenomas. 150

Based on this information, data from the Vitamins and Lifestyle study, from approximately 68,000 residents from Washington state 50-76 years old, were examined for an association between EPA and DHA intake (via fish oil supplements) or dark fish consumption and CRC 
risk. ${ }^{151}$ Individuals who took fish oil supplements (4 or more days/week) for 3 or more years, compared with non-users, had a $49 \%$ lower risk of CRC (95\% CI, 0.26-1.00). This was due to decreased risk of tumors in the colon (hazard ratio, 0.37; 95\% CI, 0.15-0.91) rather than rectum (hazard ratio, 0.98; 95\% CI, 0.35-2.69), and reductions in CRC in men (hazard ratio, 0.22; 95\% CI, 0.06-0.90) rather than in women (hazard ratio, 0.85; 95\% CI, 0.39-1.80). The multicenter, randomized Systematic Evaluation of Aspirin and Fish Oil (SEAFOOD) Polyp Prevention trial compared the effects of EPA and ASA, alone or in combination, vs placebo in prevention of colorectal adenomas. It found no effect for EPA or ASA on the adenoma detection rate at the 1-year surveillance colonoscopy. However, there was a difference based on polyp histology and location. ${ }^{152}$ EPA was significantly associated with decreases in left-sided and conventional adenomas, but not right-sided or serrated lesions, whereas ASA significantly reduced numbers of conventional adenomas, serrated lesions, and right-sided polyps. Despite their excellent safety and tolerability profiles, further studies are needed on the effects of EPA and DHA in CRC and adenoma chemoprevention.

\section{Vitamins and Minerals}

\section{Antioxidants}

Antioxidants are found in fruits, vegetables, and over-the-counter dietary supplements. High concentrations of free radicals in cells can lead to DNA, protein, and cell membrane damage; antioxidants help to reduce this oxidative stress by neutralizing free radicals (Table 1). Multiple observational studies of the role of antioxidants (vitamins A, C, and E, betacarotene, and selenium) in CRC prevention have yielded mixed results. A pooled analysis of 13 cohort studies found that intake of vitamins A, C, and E from diet alone were not associated with CRC risk. ${ }^{153}$ However, total intake of vitamins $\mathrm{C}$ and $\mathrm{E}$ from diet and supplements combined showed a modest decrease in CRC risk (vitamin C relative risk, 0.81; 95\% CI, 0.71-0.92 and vitamin E relative risk, 0.78; 95\% CI, 0.66-0.92). After adjustment for total folate intake, the relative risk, for vitamins $\mathrm{C}$ and $\mathrm{E}$ decreased slightly, but remained significant.

Observational studies of vitamins and minerals are particularly prone to recall bias and difficulties in accurate assessment of dietary intake. There is also potential confounding by other healthy behaviors shared among individuals who regularly take dietary supplements and information on CRC screening practices and over-the-counter NSAID use is often lacking. Therefore, RCTs provide the most reliable source for information about antioxidants. Meta-analyses of RCTs examining the effects of antioxidants on CRC and adenoma risks have not produced encouraging results. ${ }^{154,}{ }^{155} \mathrm{~A}$ meta-analysis of $12 \mathrm{RCTs}$ concluded that vitamins A, C, and E, selenium, and beta-carotene are not effective chemopreventive agents for colorectal neoplasia in the general population, alone, or in combination with other antioxidants or chemopreventive agents. ${ }^{155}$ In fact, 1 study included in this meta-analysis showed an increased risk of adenoma development among users of vitamin $\mathrm{E}$ (relative risk, 1.74; 95\% CI, 1.09-1.79) or vitamin E plus beta-carotene (relative risk, 1.63 ; 95\% CI, 1.01-2.64). ${ }^{156}$ This evidence is consistent with the USPSTF recommendations against the use of beta-carotene and vitamin $\mathrm{E}$ for cancer prevention and 
their conclusions that there is insufficient evidence to recommend multivitamins or other single- or paired-nutrient supplements as chemopreventive agents. ${ }^{157}$

\section{Folic Acid}

In addition to containing antioxidants, fruits and vegetables are good sources of folate (folic acid), which is part of the 1-carbon metabolic pathway required for DNA synthesis, repair, and methylation. ${ }^{158}$ Disruptions of this pathway can contribute to carcinogenesis. Epidemiology studies have associated a low-folate diet with increased risk of colorectal neoplasia. ${ }^{159-161}$ The Nurses' Health Study ${ }^{162}$ and the Canadian National Breast Screening Study ${ }^{163}$ found an inverse association between folate intake and CRC risk (relative risk, $0.25 ; 95 \% \mathrm{CI}, 0.1-0-.51$ and relative risk $0.69 ; 95 \% \mathrm{CI}, 0.52-0.93$, respectively). However, rodent studies have found folate deficiency to reduce risk, and folate supplementation to increase risk, of colorectal tumor development. ${ }^{158,164,165}$ Folate intake might therefore protect against adenoma formation but promote progression of existing colorectal neoplasias. ${ }^{166}$

RCTs examining the effect of folic acid supplementation on recurrence of colorectal adenomas as the primary endpoint have reported conflicting results, ranging from a $56 \%$ decrease in adenoma recurrence, ${ }^{167}$ to a $67 \%$ increase in advanced adenomas, ${ }^{168}$ to no significant effect. ${ }^{50,169,170}$ A meta-analysis confirmed that there were no significant effects on adenoma recurrence in high-risk (relative risk, 0.93 ; 95\% CI, 0.61-1.41) or average-risk (relative risk $1.13 ; 95 \% \mathrm{CI}, 0.77-1.64$ ) populations. ${ }^{171}$ This finding was replicated in a meta-analysis of 8 RCTs, ${ }^{172}$ in which subgroup analyses found no effects of ethnicity, sex, or body mass index. So, there is no convincing evidence that folic acid is an effective chemopreventive agent for CRC or adenomas in average-risk or high-risk populations. Studies to evaluate the effects of folate intake should include longer durations of follow up, consider various methods of folate status assessment, ${ }^{173}$ and might need to account for the effects of polymorphisms in genes involved in the folate metabolism pathway. ${ }^{174}$

\section{Calcium and Vitamin D}

Mouse studies have shown calcium and vitamin D to have potential anti-neoplastic effects in the colon. ${ }^{175-177}$ Calcium might prevent colorectal carcinogenesis via its bile acid-binding capacity and/or direct effects on calcium-sensing receptors on colonocytes. ${ }^{178,} 179$ Colonocytes express vitamin D receptors and activation of these receptors inhibits proliferation and angiogenesis, induces differentiation, and promotes apoptosis in epithelial tissues. ${ }^{176,180,181}$ Epidemiology studies have found calcium and vitamin D to reduce the risk of colorectal neoplasia by 20\%-30\%, ${ }^{182-184}$ although findings from some of the studies were limited to the distal colon and rectum. ${ }^{185}, 186$ Data from RCTs, however, have been inconsistent. The Calcium Polyp Prevention Study Group trial assigned 930 individuals with prior adenomas to groups given $3 \mathrm{~g}$ calcium carbonate or placebo and found a significantly decreased risk of adenomas in the calcium group (relative risk, 0.85; 95\% CI, 0.74-0.98). ${ }^{187}$ In contrast, in the Women's Health Study, ${ }^{188}$ in which approximately half of participants received $500 \mathrm{mg}$ of calcium carbonate and $200 \mathrm{IU}$ vitamin $\mathrm{D}_{3}$ twice daily vs placebo for an average of 7 years, no significant difference was observed in CRC incidence between the 
groups. Inconsistent results from some RCTs have been attributed to short duration of follow up and possible suboptimal doses of calcium and vitamin D. ${ }^{166}$

After the success of the Calcium Polyp Prevention Study Group trial, ${ }^{187}$ Baron et al ${ }^{180}$ examined the effects of calcium and vitamin D on prevention of adenomas in individuals with a history of 1 or more adenoma removal within 120 days prior to enrollment. They addressed the concern of suboptimal doses of calcium and vitamin D in earlier studies by substantially increasing both doses, yet remaining within what was believed to be a safe range for daily intake (2000 IU vitamin D and $2.5 \mathrm{~g}$ calcium). Participants were randomly assigned to groups that received vitamin $\mathrm{D}_{3}$ (1000 IU), calcium carbonate (1200 mg), calcium plus vitamin $\mathrm{D}_{3}$, or placebo. There was no significant reduction in adenoma risk in any of the groups over a 3-5-year period. One potential explanation for this observation could be that calcium and vitamin $\mathrm{D}_{3}$ affect later stages of adenoma development. Secondary analyses of data from this trial examined post-treatment occurrence of conventional adenomas ${ }^{189}$ and serrated polyps. ${ }^{190}$ The relative risk of conventional adenomas did not differ significantly among groups. ${ }^{189}$ However, the calcium-alone groups had a significant increase in sessile serrated adenomas and polyps (relative risk, 2.65; 95\% CI, 1.43-4.91), as did the groups that received calcium plus vitamin $\mathrm{D}_{3}$ (relative risk, 3.81; 95\% CI, 1.25-11.64). ${ }^{190}$ One limitation of the serrated polyp analysis was that the original trial was powered to evaluate conventional adenomas, which are more common. In addition, detection of sessile serrated adenomas and polyps has continued to improve over time. ${ }^{190}$ The USPSTF and the Institute of Medicine have called for new trials of higher doses of vitamin D to clarify the risk:benefit ratio of vitamin D supplementation in prevention of cancer and cardiovascular risk. ${ }^{191}$ The vitamin D and omega-3 trial was designed to evaluate the effects of vitamin $\mathrm{D}_{3}$ (2000 IU/day), with or without marine omega-3 fatty acids (1000 $\mathrm{mg} /$ day), vs placebo on primary prevention of CVD and invasive cancer (any type). ${ }^{192}$ The investigators found no significant difference in incidence of CRC among groups. So, there are not enough data to support use of calcium or vitamin D supplements for prevention of CRC or adenomas. Further studies are needed to define the potential role of calcium and vitamin D in chemoprevention of colorectal neoplasia, such as investigations into different effects on tumor or polyp location, polyp histology, and modification of effect by variants in the vitamin D receptor gene. ${ }^{193}$

\section{Agents in Development}

Many of the newest chemopreventive agents for colorectal neoplasia have been or are being tested in patients with FAP. The agents with the most promise are difluoromethylornithine (DFMO) and erlotinib. DFMO is an irreversible inhibitor of ornithine decarboxylase, an enzyme required for polyamine synthesis. Adenomatous colon polyps and colorectal tumors have increased levels of ornithine decarboxylase and polyamines compared with the normal mucosa. ${ }^{194}$ A proof of principle trial, published in $2008,{ }^{195}$ found DFMO to significantly reduce adenoma recurrence in individuals with prior adenomas. In an international RCT, celecoxib was compared to celecoxib plus DFMO in patients with FAP. ${ }^{196}$ A separate RCT evaluated the efficacy and safety of the combination of DFMO and sulindac, compared with each monotherapy, for 2 years in individuals with FAP. ${ }^{197}$ Celecoxib in combination with DFMO reduced the mean number of adenomas that developed in patients by $13 \%$, but this 
value was not significantly different than for celecoxib alone. ${ }^{196}$ Final results of the DFMO and sulindac trial are pending. The main concern about DFMO is associated ototoxicity. Erlotinib is a tyrosine kinase inhibitor that blocks epidermal growth factor receptors. Findings from studies of $A P C$ mutant zebrafish ${ }^{198}$ and human colon cancer cell lines ${ }^{198,} 199$ indicated that $A P C$ inactivation and EGFR signaling promote COX2 expression and development of intestinal neoplasia. In a trial of the effects of sulindac (150 mg twice daily) plus erlotinib (75 mg daily) vs placebo on development of duodenal neoplasia in patients with FAP, ${ }^{200}$ researchers found a $70 \%$ reduction (95\% CI, 29\%-109\%) in colorectal polyp burden in trial subjects. ${ }^{201}$

Other agents studied in patients with FAP include curcumin and guselkumab. An RCT found no significant difference in mean number or size of polyps in 44 patients with FAP given $100 \%$ pure curcumin ( $1500 \mathrm{mg}$ twice daily) vs placebo for 12 months. ${ }^{202}$ Interleukin 23 (IL23) signaling promotes CRC progression ${ }^{203-205}$; a trial is underway to investigate the effects of guselkumab, an antibody against IL23, in patients with FAP (clinicalTrials.gov no: ). ${ }^{206}$ Researchers have also aimed to develop NSAIDs with improved gastrointestinal safety profiles, such as hydrogen sulfide- and nitric oxide-releasing NSAIDs. These compounds have decreased risks for producing gastrointestinal injury and reduce numbers of $\mathrm{ACF}$ and adenomas in rodents and human cancer cell lines ${ }^{207-209}$ However, these agents are not ready for widespread clinical use.

\section{Future Directions}

Studies of CRC chemoprevention have been increasing. Although aspirin and NA-NSAIDs have shown the most promise, recommendations for their use as chemopreventive agents have been limited to individuals with increased risk of CVD or CRC predisposition syndromes, such as Lynch syndrome or FAP. For most people, the ideal CRC chemoprevention agent is elusive. Challenges to CRC chemoprevention include identification of new targetable neoplastic pathways in the colon and ways to use combinations of agents to increase efficacy and minimize toxicity. Given the overall low risk of CRC in average-risk populations, it is important to determine whether more common intermediate endpoints, such as ACF or adenomas, can be used. It is also important to identify subgroups most likely to benefit from chemoprevention agents with the lowest level of risk-possibly based on genetic factors that affect response to therapy or history of polyps and polyp subtype.

CRC chemoprevention studies face challenges such as the need for funding to support long studies that enroll large numbers of patients, and the need to validate findings in different ethnic groups and in different locations. It is important to collect accurate data on riskmany potential chemoprevention agents are available as over the counter medications or supplements and their widespread use can confound study results. It is unlikely that chemoprevention will ever replace CRC screening as the primary method for prevention. Increases in uptake of screening and decreases in CRC incidence and mortality will make it even more difficult to demonstrate the efficacy of chemoprevention strategies in clinical trials. Studies in populations undergoing regular CRC screening will therefore need to demonstrate a larger protective effect to show significant chemoprevention in addition to 
screening. In conclusion, the ideal chemopreventive agent for CRC is one that is broadly effective, safe, inexpensive, widely available, and easy to administer. Although finding a chemoprevention agent that satisfies these criteria is challenging, the possibility of decreasing CRC risk and reducing its morbidity and mortality make CRC chemoprevention an endeavor worthy of continued pursuit.

\section{Funding sources/Grant support:}

Support was provided by NIH/NIDDK K08DK106489 (BWK), the Lustgarten Family Colon Cancer Research Fund (BWK), and American Cancer Society Mentored Research Scholar Grant MRSG-13-144-01-CPHPS (JMW).

Financial disclosures: Bryson W. Katona is a current site study investigator for the Phase 1b, Multicenter, Randomized, Blinded, Placebo-controlled Study to Evaluate the Efficacy of Guselkumab in Subjects With Familial Adenomatous Polyposis (ClinicalTrials.gov ) at the University of Pennsylvania, Philadelphia, PA; he does receive salary support for his participation in the trial. Bryson W. Katona also received consulting fees from Exact Sciences as well as paid travel from Janssen. Jennifer M. Weiss was the site study investigator for the CPP FAP-310 trial (ClinicalTrials.gov) at the University of Wisconsin-Madison, Madison, WI; she received no salary support for her participation in the trial.

\section{Abbreviations:}

$\begin{array}{ll}\text { ACF } & \text { aberrant crypt foci } \\ \text { CRC } & \text { colorectal cancer } \\ \text { CI } & \text { confidence interval } \\ \text { COX } & \text { cyclooxygenase } \\ \text { CVD } & \text { cardiovascular disease } \\ \text { DHA } & \text { docosahexanoic acid } \\ \text { DMFO } & \text { difluoromethyl ornithine } \\ \text { EGFR } & \text { epidermal growth factor receptor } \\ \text { EPA } & \text { eicosapentanoic acid } \\ \text { FAP } & \text { familial adenomatous polyposis } \\ \text { NSAID } & \text { non-steroidal anti-inflammatory drug } \\ \text { NA-NSAID } & \text { non-aspirin non-steroidal anti-inflammatory drug } \\ \text { PGE } & \text { prostaglandin E2 } \\ \text { US } & \text { United States } \\ \text { USPSF } & \text { US Preventive Services Task Force } \\ \text { NA } & \end{array}$

\section{References}

1. American Cancer Society. Global Cancer Facts \& Figures 4th Edition American Cancer Society, 2018 Accessible at https://www.cancer.org/content/dam/cancer-org/research/cancer-facts-andstatistics/global-cancer-facts-and-figures/global-cancer-facts-and-figures-4th-edition.pdf. 
2. American Cancer Society. Cancer Facts \& Figures 2019 American Cancer Society, 2019. Accessible at https://www.cancer.org/latest-news/facts-and-figures-2019.html.

3. Schoen RE, Pinsky PF, Weissfeld JL, et al. Colorectal-cancer incidence and mortality with screening flexible sigmoidoscopy. N Engl J Med 2012;366:2345-57. [PubMed: 22612596]

4. Nishihara R, Wu K, Lochhead P, et al. Long-term colorectal-cancer incidence and mortality after lower endoscopy. N Engl J Med 2013;369:1095-105. [PubMed: 24047059]

5. Shaukat A, Mongin SJ, Geisser MS, et al. Long-term mortality after screening for colorectal cancer. N Engl J Med 2013;369:1106-14. [PubMed: 24047060]

6. Levin TR, Corley DA, Jensen CD, et al. Effects of Organized Colorectal Cancer Screening on Cancer Incidence and Mortality in a Large Community-Based Population. Gastroenterology 2018;155:1383-1391 e5. [PubMed: 30031768]

7. Doubeni CA, Corley DA, Quinn VP, et al. Effectiveness of screening colonoscopy in reducing the risk of death from right and left colon cancer: a large community-based study. Gut 2018;67:291298. [PubMed: 27733426]

8. Fakih MG. Metastatic colorectal cancer: current state and future directions. J Clin Oncol 2015;33:1809-24. [PubMed: 25918280]

9. Sporn MB. Approaches to prevention of epithelial cancer during the preneoplastic period. Cancer Res 1976;36:2699-702. [PubMed: 1277177]

10. Al Rabadi L, Bergan R. A Way Forward for Cancer Chemoprevention: Think Local. Cancer Prev Res (Phila) 2017;10:14-35. [PubMed: 27780807]

11. Grady WM, Markowitz SD. The molecular pathogenesis of colorectal cancer and its potential application to colorectal cancer screening. Dig Dis Sci 2015;60:762-72. [PubMed: 25492499]

12. Coleman HG, Loughrey MB, Murray LJ, et al. Colorectal Cancer Risk Following Adenoma Removal: A Large Prospective Population-Based Cohort Study. Cancer Epidemiol Biomarkers Prev 2015;24:1373-80. [PubMed: 26082403]

13. Winawer SJ, Zauber AG, Ho MN, et al. Prevention of colorectal cancer by colonoscopic polypectomy. The National Polyp Study Workgroup. N Engl J Med 1993;329:1977-81. [PubMed: 8247072]

14. Brenner H, Chang-Claude J, Seiler CM, et al. Protection from colorectal cancer after colonoscopy: a population-based, case-control study. Ann Intern Med 2011;154:22-30. [PubMed: 21200035]

15. Bird RP. Observation and quantification of aberrant crypts in the murine colon treated with a colon carcinogen: preliminary findings. Cancer Lett 1987;37:147-51. [PubMed: 3677050]

16. McLellan EA, Bird RP. Aberrant crypts: potential preneoplastic lesions in the murine colon. Cancer Res 1988;48:6187-92. [PubMed: 3167865]

17. Takayama T, Katsuki S, Takahashi Y, et al. Aberrant crypt foci of the colon as precursors of adenoma and cancer. N Engl J Med 1998;339:1277-84. [PubMed: 9791143]

18. Gupta AK, Pinsky P, Rall C, et al. Reliability and accuracy of the endoscopic appearance in the identification of aberrant crypt foci. Gastrointest Endosc 2009;70:322-30. [PubMed: 19539919]

19. Lance P, Hamilton SR. Sporadic aberrant crypt foci are not a surrogate endpoint for colorectal adenoma prevention. Cancer Prev Res (Phila) 2008;1:4-8. [PubMed: 19138929]

20. Fuster V, Sweeny JM. Aspirin: a historical and contemporary therapeutic overview. Circulation 2011;123:768-78. [PubMed: 21343593]

21. Drew DA, Cao Y, Chan AT. Aspirin and colorectal cancer: the promise of precision chemoprevention. Nat Rev Cancer 2016;16:173-86. [PubMed: 26868177]

22. Rothwell PM, Price JF, Fowkes FG, et al. Short-term effects of daily aspirin on cancer incidence, mortality, and non-vascular death: analysis of the time course of risks and benefits in 51 randomised controlled trials. Lancet 2012;379:1602-12. [PubMed: 22440946]

23. Chubak J, Whitlock EP, Williams SB, et al. Aspirin for the Prevention of Cancer Incidence and Mortality: Systematic Evidence Reviews for the U.S. Preventive Services Task Force. Ann Intern Med 2016;164:814-25. [PubMed: 27064482]

24. Kune GA, Kune S, Watson LF. Colorectal cancer risk, chronic illnesses, operations, and medications: case control results from the Melbourne Colorectal Cancer Study. Cancer Res 1988;48:4399-404. [PubMed: 3390835] 
25. Craven PA, DeRubertis FR. Effects of aspirin on 1,2-dimethylhydrazine-induced colonic carcinogenesis. Carcinogenesis 1992;13:541-6. [PubMed: 1315625]

26. Reddy BS, Rao CV, Rivenson A, et al. Inhibitory effect of aspirin on azoxymethane-induced colon carcinogenesis in F344 rats. Carcinogenesis 1993;14:1493-7. [PubMed: 8353834]

27. Barnes CJ, Lee M. Chemoprevention of spontaneous intestinal adenomas in the adenomatous polyposis coli Min mouse model with aspirin. Gastroenterology 1998;114:873-7. [PubMed: 9558273]

28. Bibbins-Domingo K, Force USPST. Aspirin Use for the Primary Prevention of Cardiovascular Disease and Colorectal Cancer: U.S. Preventive Services Task Force Recommendation Statement. Ann Intern Med 2016;164:836-45. [PubMed: 27064677]

29. Dehmer SP, Maciosek MV, Flottemesch TJ, et al. Aspirin for the Primary Prevention of Cardiovascular Disease and Colorectal Cancer: A Decision Analysis for the U.S. Preventive Services Task Force. Ann Intern Med 2016;164:777-86. [PubMed: 27064573]

30. Friis S, Riis AH, Erichsen R, et al. Low-Dose Aspirin or Nonsteroidal Anti-inflammatory Drug Use and Colorectal Cancer Risk: A Population-Based, Case-Control Study. Ann Intern Med 2015;163:347-55. [PubMed: 26302241]

31. Chan AT, Giovannucci EL, Meyerhardt JA, et al. Aspirin dose and duration of use and risk of colorectal cancer in men. Gastroenterology 2008;134:21-8. [PubMed: 18005960]

32. Giovannucci E, Rimm EB, Stampfer MJ, et al. Aspirin use and the risk for colorectal cancer and adenoma in male health professionals. Ann Intern Med 1994;121:241-6. [PubMed: 8037405]

33. Giovannucci E, Egan KM, Hunter DJ, et al. Aspirin and the risk of colorectal cancer in women. N Engl J Med 1995;333:609-14. [PubMed: 7637720]

34. Cao Y, Nishihara R, Wu K, et al. Population-wide Impact of Long-term Use of Aspirin and the Risk for Cancer. JAMA Oncol 2016;2:762-9. [PubMed: 26940135]

35. Jacobs EJ, Thun MJ, Bain EB, et al. A large cohort study of long-term daily use of adult-strength aspirin and cancer incidence. J Natl Cancer Inst 2007;99:608-15. [PubMed: 17440162]

36. Cook NR, Lee IM, Gaziano JM, et al. Low-dose aspirin in the primary prevention of cancer: the Women's Health Study: a randomized controlled trial. JAMA 2005;294:47-55. [PubMed: 15998890]

37. Cook NR, Lee IM, Zhang SM, et al. Alternate-day, low-dose aspirin and cancer risk: long-term observational follow-up of a randomized trial. Ann Intern Med 2013;159:77-85. [PubMed: 23856681]

38. Flossmann E, Rothwell PM, British Doctors Aspirin T, et al. Effect of aspirin on long-term risk of colorectal cancer: consistent evidence from randomised and observational studies. Lancet 2007;369:1603-13. [PubMed: 17499602]

39. Rothwell PM, Wilson M, Elwin CE, et al. Long-term effect of aspirin on colorectal cancer incidence and mortality: 20-year follow-up of five randomised trials. Lancet 2010;376:1741-50. [PubMed: 20970847]

40. Algra AM, Rothwell PM. Effects of regular aspirin on long-term cancer incidence and metastasis: a systematic comparison of evidence from observational studies versus randomised trials. Lancet Oncol 2012;13:518-27. [PubMed: 22440112]

41. Gann PH, Manson JE, Glynn RJ, et al. Low-dose aspirin and incidence of colorectal tumors in a randomized trial. J Natl Cancer Inst 1993;85:1220-4. [PubMed: 8331682]

42. Sturmer T, Glynn RJ, Lee IM, et al. Aspirin use and colorectal cancer: post-trial follow-up data from the Physicians' Health Study. Ann Intern Med 1998;128:713-20. [PubMed: 9556464]

43. McNeil JJ, Nelson MR, Woods RL, et al. Effect of Aspirin on All-Cause Mortality in the Healthy Elderly. N Engl J Med 2018;379:1519-1528. [PubMed: 30221595]

44. Baron JA, Cole BF, Sandler RS, et al. A randomized trial of aspirin to prevent colorectal adenomas. N Engl J Med 2003;348:891-9. [PubMed: 12621133]

45. Benamouzig R, Deyra J, Martin A, et al. Daily soluble aspirin and prevention of colorectal adenoma recurrence: one-year results of the APACC trial. Gastroenterology 2003;125:328-36. [PubMed: 12891533] 
46. Benamouzig R, Uzzan B, Deyra J, et al. Prevention by daily soluble aspirin of colorectal adenoma recurrence: 4-year results of the APACC randomised trial. Gut 2012;61:255-61. [PubMed: 21890814]

47. Ishikawa H, Mutoh M, Suzuki S, et al. The preventive effects of low-dose enteric-coated aspirin tablets on the development of colorectal tumours in Asian patients: a randomised trial. Gut 2014;63:1755-9. [PubMed: 24488498]

48. Drew DA, Goh G, Mo A, et al. Colorectal polyp prevention by daily aspirin use is abrogated among active smokers. Cancer Causes Control 2016;27:93-103. [PubMed: 26510933]

49. Sandler RS, Halabi S, Baron JA, et al. A randomized trial of aspirin to prevent colorectal adenomas in patients with previous colorectal cancer. N Engl J Med 2003;348:883-90. [PubMed: 12621132]

50. Logan RF, Grainge MJ, Shepherd VC, et al. Aspirin and folic acid for the prevention of recurrent colorectal adenomas. Gastroenterology 2008;134:29-38. [PubMed: 18022173]

51. Murff HJ, Shrubsole MJ, Chen Z, et al. Nonsteroidal anti-inflammatory drug use and risk of adenomatous and hyperplastic polyps. Cancer Prev Res (Phila) 2011;4:1799-807. [PubMed: 21764857]

52. Cole BF, Logan RF, Halabi S, et al. Aspirin for the chemoprevention of colorectal adenomas: metaanalysis of the randomized trials. J Natl Cancer Inst 2009;101:256-66. [PubMed: 19211452]

53. Chan AT, Giovannucci EL, Schernhammer ES, et al. A prospective study of aspirin use and the risk for colorectal adenoma. Ann Intern Med 2004;140:157-66. [PubMed: 14757613]

54. Burn J, Bishop DT, Chapman PD, et al. A randomized placebo-controlled prevention trial of aspirin and/or resistant starch in young people with familial adenomatous polyposis. Cancer Prev Res (Phila) 2011;4:655-65. [PubMed: 21543343]

55. Burn J, Bishop DT, Mecklin JP, et al. Effect of aspirin or resistant starch on colorectal neoplasia in the Lynch syndrome. N Engl J Med 2008;359:2567-78. [PubMed: 19073976]

56. Burn J, Gerdes AM, Macrae F, et al. Long-term effect of aspirin on cancer risk in carriers of hereditary colorectal cancer: an analysis from the CAPP2 randomised controlled trial. Lancet 2011;378:2081-7. [PubMed: 22036019]

57. Ait Ouakrim D, Dashti SG, Chau R, et al. Aspirin, Ibuprofen, and the Risk of Colorectal Cancer in Lynch Syndrome. J Natl Cancer Inst 2015;107.

58. Elwood PC, Morgan G, Pickering JE, et al. Aspirin in the Treatment of Cancer: Reductions in Metastatic Spread and in Mortality: A Systematic Review and Meta-Analyses of Published Studies. PLoS One 2016;11:e0152402. [PubMed: 27096951]

59. Liao X, Lochhead P, Nishihara R, et al. Aspirin use, tumor PIK3CA mutation, and colorectalcancer survival. N Engl J Med 2012;367:1596-606. [PubMed: 23094721]

60. McNeil JJ, Wolfe R, Woods RL, et al. Effect of Aspirin on Cardiovascular Events and Bleeding in the Healthy Elderly. N Engl J Med 2018;379:1509-1518. [PubMed: 30221597]

61. Gaziano JM, Brotons C, Coppolecchia R, et al. Use of aspirin to reduce risk of initial vascular events in patients at moderate risk of cardiovascular disease (ARRIVE): a randomised, doubleblind, placebo-controlled trial. Lancet 2018;392:1036-1046. [PubMed: 30158069]

62. Ali R, Toh HC, Chia WK, et al. The utility of Aspirin in Dukes C and High Risk Dukes B Colorectal cancer--the ASCOLT study: study protocol for a randomized controlled trial. Trials 2011;12:261. [PubMed: 22168568]

63. Mackenzie TC, Howell LJ, Flake AW, et al. The management of prenatally diagnosed choledochal cysts. J Pediatr Surg 2001;36:1241-3. [PubMed: 11479866]

64. Coyle C, Cafferty FH, Rowley S, et al. ADD-ASPIRIN: A phase III, double-blind, placebo controlled, randomised trial assessing the effects of aspirin on disease recurrence and survival after primary therapy in common non-metastatic solid tumours. Contemp Clin Trials 2016;51:56-64. [PubMed: 27777129]

65. Finding the best dose of aspirin to prevent Lynch Syndrome cancers. CaPP3 Trial. ISRCTN Registry, ISRCTN16261285. Accessible at: 10.1186/ISRCTN16261285.

66. Drew DA, Chin SM, Gilpin KK, et al. ASPirin Intervention for the REDuction of colorectal cancer risk (ASPIRED): a study protocol for a randomized controlled trial. Trials 2017;18:50. [PubMed: 28143522] 
67. Rodriguez-Miguel A, Garcia-Rodriguez LA, Gil M, et al. Clopidogrel and Low-Dose Aspirin, Alone or Together, Reduce Risk of Colorectal Cancer. Clin Gastroenterol Hepatol 2018.

68. Chan AT, Ogino S, Fuchs CS. Aspirin and the risk of colorectal cancer in relation to the expression of COX-2. N Engl J Med 2007;356:2131-42. [PubMed: 17522398]

69. Nan H, Hutter CM, Lin Y, et al. Association of aspirin and NSAID use with risk of colorectal cancer according to genetic variants. JAMA 2015;313:1133-42. [PubMed: 25781442]

70. Emilsson L, Holme O, Bretthauer M, et al. Systematic review with meta-analysis: the comparative effectiveness of aspirin vs. screening for colorectal cancer prevention. Aliment Pharmacol Ther 2017;45:193-204. [PubMed: 27859394]

71. Mohammed A, Yarla NS, Madka V, et al. Clinically Relevant Anti-Inflammatory Agents for Chemoprevention of Colorectal Cancer: New Perspectives. Int J Mol Sci 2018;19.

72. Jaffe BM. Prostaglandins and cancer: an update. Prostaglandins 1974;6:453-61. [PubMed: 4366016]

73. Bennett A, Del Tacca M. Proceedings: Prostaglandins in human colonic carcinoma. Gut 1975;16:409.

74. Corpet DE, Pierre F. Point: From animal models to prevention of colon cancer. Systematic review of chemoprevention in min mice and choice of the model system. Cancer Epidemiol Biomarkers Prev 2003;12:391-400. [PubMed: 12750232]

75. Hawk ET, Levin B. Colorectal cancer prevention. J Clin Oncol 2005;23:378-91. [PubMed: 15637400]

76. Fischer SM, Hawk ET, Lubet RA. Coxibs and other nonsteroidal anti-inflammatory drugs in animal models of cancer chemoprevention. Cancer Prev Res (Phila) 2011;4:1728-35. [PubMed: 21778329]

77. Reeves MJ, Newcomb PA, Trentham-Dietz A, et al. Nonsteroidal anti-inflammatory drug use and protection against colorectal cancer in women. Cancer Epidemiol Biomarkers Prev 1996;5:955-60. [PubMed: 8959316]

78. Harris RE, Beebe-Donk J, Alshafie GA. Similar reductions in the risk of human colon cancer by selective and nonselective cyclooxygenase-2 (COX-2) inhibitors. BMC Cancer 2008;8:237. [PubMed: 18702823]

79. Tomic T, Dominguez-Lopez S, Barrios-Rodriguez R. Non-aspirin non-steroidal anti-inflammatory drugs in prevention of colorectal cancer in people aged 40 or older: A systematic review and metaanalysis. Cancer Epidemiol 2019;58:52-62. [PubMed: 30472477]

80. Giardiello FM, Hamilton SR, Krush AJ, et al. Treatment of colonic and rectal adenomas with sulindac in familial adenomatous polyposis. N Engl J Med 1993;328:1313-6. [PubMed: 8385741]

81. Cruz-Correa M, Hylind LM, Romans KE, et al. Long-term treatment with sulindac in familial adenomatous polyposis: a prospective cohort study. Gastroenterology 2002;122:641-5. [PubMed: 11874996]

82. Giardiello FM, Yang VW, Hylind LM, et al. Primary chemoprevention of familial adenomatous polyposis with sulindac. N Engl J Med 2002;346:1054-9. [PubMed: 11932472]

83. Takayama T, Nagashima H, Maeda M, et al. Randomized double-blind trial of sulindac and etodolac to eradicate aberrant crypt foci and to prevent sporadic colorectal polyps. Clin Cancer Res 2011;17:3803-11. [PubMed: 21385928]

84. Naproxen in Preventing DNA Mismatch Repair Deficient Colorectal Cancer in Patients With Lynch Syndrome. ClinicalTrials.gov, NCT02052908. Accessible at: https://clinicaltrials.gov/ct2/ show/NCT02052908.

85. Ross SJ, Elgendy IY, Bavry AA. Cardiovascular Safety and Bleeding Risk Associated with Nonsteroidal Anti-Inflammatory Medications in Patients with Cardiovascular Disease. Curr Cardiol Rep 2017;19:8. [PubMed: 28138824]

86. Arber N, Eagle CJ, Spicak J, et al. Celecoxib for the prevention of colorectal adenomatous polyps. N Engl J Med 2006;355:885-95. [PubMed: 16943401]

87. Bertagnolli MM, Eagle CJ, Zauber AG, et al. Celecoxib for the prevention of sporadic colorectal adenomas. N Engl J Med 2006;355:873-84. [PubMed: 16943400] 
88. Bertagnolli MM, Eagle CJ, Zauber AG, et al. Five-year efficacy and safety analysis of the Adenoma Prevention with Celecoxib Trial. Cancer Prev Res (Phila) 2009;2:310-21. [PubMed: 19336730]

89. Wang J, Cho NL, Zauber AG, et al. Chemopreventive Efficacy of the Cyclooxygenase-2 (Cox-2) Inhibitor, Celecoxib, Is Predicted by Adenoma Expression of Cox-2 and 15-PGDH. Cancer Epidemiol Biomarkers Prev 2018;27:728-736. [PubMed: 29769213]

90. Steinbach G, Lynch PM, Phillips RK, et al. The effect of celecoxib, a cyclooxygenase-2 inhibitor, in familial adenomatous polyposis. N Engl J Med 2000;342:1946-52. [PubMed: 10874062]

91. Higuchi T, Iwama T, Yoshinaga K, et al. A randomized, double-blind, placebo-controlled trial of the effects of rofecoxib, a selective cyclooxygenase- 2 inhibitor, on rectal polyps in familial adenomatous polyposis patients. Clin Cancer Res 2003;9:4756-60. [PubMed: 14581346]

92. Baron JA, Sandler RS, Bresalier RS, et al. A randomized trial of rofecoxib for the chemoprevention of colorectal adenomas. Gastroenterology 2006;131:1674-82. [PubMed: 17087947]

93. Bresalier RS, Sandler RS, Quan H, et al. Cardiovascular events associated with rofecoxib in a colorectal adenoma chemoprevention trial. N Engl J Med 2005;352:1092-102. [PubMed: 15713943]

94. Solomon SD, McMurray JJ, Pfeffer MA, et al. Cardiovascular risk associated with celecoxib in a clinical trial for colorectal adenoma prevention. N Engl J Med 2005;352:1071-80. [PubMed: 15713944]

95. Rostom A, Dube C, Lewin G, et al. Nonsteroidal anti-inflammatory drugs and cyclooxygenase-2 inhibitors for primary prevention of colorectal cancer: a systematic review prepared for the U.S. Preventive Services Task Force. Ann Intern Med 2007;146:376-89. [PubMed: 17339623]

96. Larsson SC, Orsini N, Wolk A. Diabetes mellitus and risk of colorectal cancer: a meta-analysis. J Natl Cancer Inst 2005;97:1679-87. [PubMed: 16288121]

97. Zhou G, Myers R, Li Y, et al. Role of AMP-activated protein kinase in mechanism of metformin action. J Clin Invest 2001;108:1167-74. [PubMed: 11602624]

98. Hay N. The Akt-mTOR tango and its relevance to cancer. Cancer Cell 2005;8:179-83. [PubMed: 16169463]

99. Hosono K, Endo H, Takahashi H, et al. Metformin suppresses azoxymethane-induced colorectal aberrant crypt foci by activating AMP-activated protein kinase. Mol Carcinog 2010;49:662-71. [PubMed: 20564343]

100. Ben Sahra I, Laurent K, Loubat A, et al. The antidiabetic drug metformin exerts an antitumoral effect in vitro and in vivo through a decrease of cyclin D1 level. Oncogene 2008;27:3576-86. [PubMed: 18212742]

101. Tomimoto A, Endo H, Sugiyama M, et al. Metformin suppresses intestinal polyp growth in ApcMin/+ mice. Cancer Sci 2008;99:2136-41. [PubMed: 18803638]

102. Cardel M, Jensen SM, Pottegard A, et al. Long-term use of metformin and colorectal cancer risk in type II diabetics: a population-based case-control study. Cancer Med 2014;3:1458-66. [PubMed: 25091592]

103. Currie CJ, Poole CD, Gale EA. The influence of glucose-lowering therapies on cancer risk in type 2 diabetes. Diabetologia 2009;52:1766-77. [PubMed: 19572116]

104. Lee MS, Hsu CC, Wahlqvist ML, et al. Type 2 diabetes increases and metformin reduces total, colorectal, liver and pancreatic cancer incidences in Taiwanese: a representative population prospective cohort study of 800,000 individuals. BMC Cancer 2011;11:20. [PubMed: 21241523]

105. Libby G, Donnelly LA, Donnan PT, et al. New users of metformin are at low risk of incident cancer: a cohort study among people with type 2 diabetes. Diabetes Care 2009;32:1620-5. [PubMed: 19564453]

106. Sehdev A, Shih YC, Vekhter B, et al. Metformin for primary colorectal cancer prevention in patients with diabetes: a case-control study in a US population. Cancer 2015;121:1071-8. [PubMed: 25424411]

107. Tseng CH. Diabetes, metformin use, and colon cancer: a population-based cohort study in Taiwan. Eur J Endocrinol 2012;167:409-16. [PubMed: 22778198] 
108. Zhang ZJ, Zheng ZJ, Kan H, et al. Reduced risk of colorectal cancer with metformin therapy in patients with type 2 diabetes: a meta-analysis. Diabetes Care 2011;34:2323-8. [PubMed: 21949223]

109. Kowall B, Stang A, Rathmann W, et al. No reduced risk of overall, colorectal, lung, breast, and prostate cancer with metformin therapy in diabetic patients: database analyses from Germany and the UK. Pharmacoepidemiol Drug Saf 2015;24:865-74. [PubMed: 26132313]

110. Lin CM, Huang HL, Chu FY, et al. Association between Gastroenterological Malignancy and Diabetes Mellitus and Anti-Diabetic Therapy: A Nationwide, Population-Based Cohort Study. PLoS One 2015;10:e0125421. [PubMed: 25978841]

111. Smiechowski B, Azoulay L, Yin H, et al. The use of metformin and colorectal cancer incidence in patients with type II diabetes mellitus. Cancer Epidemiol Biomarkers Prev 2013;22:1877-83. [PubMed: 23966577]

112. Bodmer M, Becker C, Meier C, et al. Use of metformin is not associated with a decreased risk of colorectal cancer: a case-control analysis. Cancer Epidemiol Biomarkers Prev 2012;21:280-6. [PubMed: 22178569]

113. Knapen LM, Dittrich ST, de Vries F, et al. Use of biguanides and the risk of colorectal cancer: a register-based cohort study. Curr Drug Saf 2013;8:349-56. [PubMed: 24215310]

114. Bradley MC, Ferrara A, Achacoso N, et al. A Cohort Study of Metformin and Colorectal Cancer Risk among Patients with Diabetes Mellitus. Cancer Epidemiol Biomarkers Prev 2018;27:525530. [PubMed: 29716927]

115. Singh S, Singh H, Singh PP, et al. Antidiabetic medications and the risk of colorectal cancer in patients with diabetes mellitus: a systematic review and meta-analysis. Cancer Epidemiol Biomarkers Prev 2013;22:2258-68. [PubMed: 24042261]

116. Jung YS, Park CH, Eun CS, et al. Metformin use and the risk of colorectal adenoma: A systematic review and meta-analysis. J Gastroenterol Hepatol 2017;32:957-965. [PubMed: 28449338]

117. Higurashi T, Hosono K, Takahashi H, et al. Metformin for chemoprevention of metachronous colorectal adenoma or polyps in post-polypectomy patients without diabetes: a multicentre double-blind, placebo-controlled, randomised phase 3 trial. Lancet Oncol 2016;17:475-483. [PubMed: 26947328]

118. Liu F, Yan L, Wang Z, et al. Metformin therapy and risk of colorectal adenomas and colorectal cancer in type 2 diabetes mellitus patients: A systematic review and meta-analysis. Oncotarget 2017;8:16017-16026. [PubMed: 27926481]

119. Gu Q, Paulose-Ram R, Burt VL, et al. Prescription cholesterol-lowering medication use in adults aged 40 and over: United States, 2003-2012. NCHS Data Brief 2014:1-8.

120. Gazzerro P, Proto MC, Gangemi G, et al. Pharmacological actions of statins: a critical appraisal in the management of cancer. Pharmacol Rev 2012;64:102-46. [PubMed: 22106090]

121. Chan KK, Oza AM, Siu LL. The statins as anticancer agents. Clin Cancer Res 2003;9:10-9. [PubMed: 12538446]

122. Wachtershauser A, Akoglu B, Stein J. HMG-CoA reductase inhibitor mevastatin enhances the growth inhibitory effect of butyrate in the colorectal carcinoma cell line Caco-2. Carcinogenesis 2001;22:1061-7. [PubMed: 11408350]

123. Qi XF, Kim DH, Yoon YS, et al. Involvement of oxidative stress in simvastatin-induced apoptosis of murine CT26 colon carcinoma cells. Toxicol Lett 2010;199:277-87. [PubMed: 20883752]

124. Teraoka N, Mutoh M, Takasu S, et al. Inhibition of intestinal polyp formation by pitavastatin, a HMG-CoA reductase inhibitor. Cancer Prev Res (Phila) 2011;4:445-53. [PubMed: 21233289]

125. Suh N, Reddy BS, DeCastro A, et al. Combination of atorvastatin with sulindac or naproxen profoundly inhibits colonic adenocarcinomas by suppressing the p65/beta-catenin/cyclin D1 signaling pathway in rats. Cancer Prev Res (Phila) 2011;4:1895-902. [PubMed: 21764859]

126. Swamy MV, Patlolla JM, Steele VE, et al. Chemoprevention of familial adenomatous polyposis by low doses of atorvastatin and celecoxib given individually and in combination to APCMin mice. Cancer Res 2006;66:7370-7. [PubMed: 16849589]

127. Poynter JN, Gruber SB, Higgins PD, et al. Statins and the risk of colorectal cancer. N Engl J Med 2005;352:2184-92. [PubMed: 15917383] 
128. Lipkin SM, Chao EC, Moreno V, et al. Genetic variation in 3-hydroxy-3-methylglutaryl CoA reductase modifies the chemopreventive activity of statins for colorectal cancer. Cancer Prev Res (Phila) 2010;3:597-603. [PubMed: 20403997]

129. Farwell WR, Scranton RE, Lawler EV, et al. The association between statins and cancer incidence in a veterans population. J Natl Cancer Inst 2008;100:134-9. [PubMed: 18182618]

130. Browning DR, Martin RM. Statins and risk of cancer: a systematic review and metaanalysis. Int J Cancer 2007;120:833-43. [PubMed: 17131313]

131. Bonovas S, Filioussi K, Tsavaris N, et al. Statins and cancer risk: a literature-based meta-analysis and meta-regression analysis of 35 randomized controlled trials. J Clin Oncol 2006;24:4808-17. [PubMed: 17001070]

132. Taylor ML, Wells BJ, Smolak MJ. Statins and cancer: a meta-analysis of case-control studies. Eur J Cancer Prev 2008;17:259-68. [PubMed: 18414198]

133. Kuoppala J, Lamminpaa A, Pukkala E. Statins and cancer: A systematic review and metaanalysis. Eur J Cancer 2008;44:2122-32. [PubMed: 18707867]

134. Dale KM, Coleman CI, Henyan NN, et al. Statins and cancer risk: a meta-analysis. JAMA 2006;295:74-80. [PubMed: 16391219]

135. Boudreau DM, Yu O, Johnson J. Statin use and cancer risk: a comprehensive review. Expert Opin Drug Saf 2010;9:603-21. [PubMed: 20377474]

136. Saku K, Zhang B, Noda K, et al. Randomized head-to-head comparison of pitavastatin, atorvastatin, and rosuvastatin for safety and efficacy (quantity and quality of LDL): the PATROL trial. Circ J 2011;75:1493-505. [PubMed: 21498906]

137. Lee JE, Baba Y, Ng K, et al. Statin use and colorectal cancer risk according to molecular subtypes in two large prospective cohort studies. Cancer Prev Res (Phila) 2011;4:1808-15. [PubMed: 21680706]

138. Emilsson L, Garcia-Albeniz X, Logan RW, et al. Examining Bias in Studies of Statin Treatment and Survival in Patients With Cancer. JAMA Oncol 2018;4:63-70. [PubMed: 28822996]

139. Cholesterol Treatment Trialists C, Emberson JR, Kearney PM, et al. Lack of effect of lowering LDL cholesterol on cancer: meta-analysis of individual data from 175,000 people in 27 randomised trials of statin therapy. PLoS One 2012;7:e29849. [PubMed: 22276132]

140. Lochhead P, Chan AT. Statins and colorectal cancer. Clin Gastroenterol Hepatol 2013;11:109-18; quiz e13-4. [PubMed: 22982096]

141. Ford I, Murray H, Packard CJ, et al. Long-term follow-up of the West of Scotland Coronary Prevention Study. N Engl J Med 2007;357:1477-86. [PubMed: 17928595]

142. Heart Protection Study Collaborative G. Effects on 11-year mortality and morbidity of lowering LDL cholesterol with simvastatin for about 5 years in 20,536 high-risk individuals: a randomised controlled trial. Lancet 2011;378:2013-2020. [PubMed: 22115874]

143. Siddiqui AA, Nazario H, Mahgoub A, et al. The long-term use of statins is associated with a decreased incidence of adenomatous colon polyps. Digestion 2009;79:17-22. [PubMed: 19246916]

144. Wei JT, Mott LA, Baron JA, et al. Reported use of 3-hydroxy-3-methylglutaryl coenzyme A reductase inhibitors was not associated with reduced recurrence of colorectal adenomas. Cancer Epidemiol Biomarkers Prev 2005;14:1026-7. [PubMed: 15824186]

145. Bertagnolli MM, Hsu M, Hawk ET, et al. Statin use and colorectal adenoma risk: results from the adenoma prevention with celecoxib trial. Cancer Prev Res (Phila) 2010;3:588-96. [PubMed: 20403998]

146. Ebrahimi M, Ghayour-Mobarhan M, Rezaiean S, et al. Omega-3 fatty acid supplements improve the cardiovascular risk profile of subjects with metabolic syndrome, including markers of inflammation and auto-immunity. Acta Cardiol 2009;64:321-7. [PubMed: 19593941]

147. Cockbain AJ, Toogood GJ, Hull MA. Omega-3 polyunsaturated fatty acids for the treatment and prevention of colorectal cancer. Gut 2012;61:135-49. [PubMed: 21490374]

148. Latham P, Lund EK, Johnson IT. Dietary n-3 PUFA increases the apoptotic response to 1,2dimethylhydrazine, reduces mitosis and suppresses the induction of carcinogenesis in the rat colon. Carcinogenesis 1999;20:645-50. [PubMed: 10223194] 
149. Clarke RG, Lund EK, Latham P, et al. Effect of eicosapentaenoic acid on the proliferation and incidence of apoptosis in the colorectal cell line HT29. Lipids 1999;34:1287-95. [PubMed: 10652988]

150. West NJ, Clark SK, Phillips RK, et al. Eicosapentaenoic acid reduces rectal polyp number and size in familial adenomatous polyposis. Gut 2010;59:918-25. [PubMed: 20348368]

151. Kantor ED, Lampe JW, Peters U, et al. Long-chain omega-3 polyunsaturated fatty acid intake and risk of colorectal cancer. Nutr Cancer 2014;66:716-27. [PubMed: 24053119]

152. Hull MA, Sprange K, Hepburn T, et al. Eicosapentaenoic acid and aspirin, alone and in combination, for the prevention of colorectal adenomas (seAFOod Polyp Prevention trial): a multicentre, randomised, double-blind, placebo-controlled, $2 \times 2$ factorial trial. Lancet 2018;392:2583-2594. [PubMed: 30466866]

153. Park Y, Spiegelman D, Hunter DJ, et al. Intakes of vitamins A, C, and E and use of multiple vitamin supplements and risk of colon cancer: a pooled analysis of prospective cohort studies. Cancer Causes Control 2010;21:1745-57. [PubMed: 20820901]

154. Bjelakovic G, Nagorni A, Nikolova D, et al. Meta-analysis: antioxidant supplements for primary and secondary prevention of colorectal adenoma. Aliment Pharmacol Ther 2006;24:281-91. [PubMed: 16842454]

155. Papaioannou D, Cooper KL, Carroll C, et al. Antioxidants in the chemoprevention of colorectal cancer and colorectal adenomas in the general population: a systematic review and meta-analysis. Colorectal Dis 2011;13:1085-99. [PubMed: 20412095]

156. Malila N, Virtamo J, Virtanen M, et al. The effect of alpha-tocopherol and beta-carotene supplementation on colorectal adenomas in middle-aged male smokers. Cancer Epidemiol Biomarkers Prev 1999;8:489-93. [PubMed: 10385137]

157. US Preventive Services Task Force. Routine vitamin supplementation to prevent cancer and cardiovascular disease: recommendations and rationale. Ann Intern Med 2003;139:51-5. [PubMed: 12834319]

158. Kim YI. Current status of folic acid supplementation on colorectal cancer prevention. Curr Pharmacol Rep 2016;2:21-33.

159. Sanjoaquin MA, Allen N, Couto E, et al. Folate intake and colorectal cancer risk: a metaanalytical approach. Int J Cancer 2005;113:825-8. [PubMed: 15499620]

160. Paspatis GA, Kalafatis E, Oros L, et al. Folate status and adenomatous colonic polyps. A colonoscopically controlled study. Dis Colon Rectum 1995;38:64-7; discussion 67-8. [PubMed: 7813348]

161. Baron JA, Sandler RS, Haile RW, et al. Folate intake, alcohol consumption, cigarette smoking, and risk of colorectal adenomas. J Natl Cancer Inst 1998;90:57-62. [PubMed: 9428784]

162. Giovannucci E, Stampfer MJ, Colditz GA, et al. Multivitamin use, folate, and colon cancer in women in the Nurses' Health Study. Ann Intern Med 1998;129:517-24. [PubMed: 9758570]

163. Terry P, Jain M, Miller AB, et al. Dietary intake of folic acid and colorectal cancer risk in a cohort of women. Int J Cancer 2002;97:864-7. [PubMed: 11857369]

164. Choi SW, Mason JB. Folate and carcinogenesis: an integrated scheme. J Nutr 2000;130:129-32. [PubMed: 10720158]

165. Lindzon GM, Medline A, Sohn KJ, et al. Effect of folic acid supplementation on the progression of colorectal aberrant crypt foci. Carcinogenesis 2009;30:1536-43. [PubMed: 19541855]

166. Arber N, Levin B. Chemoprevention of colorectal neoplasia: the potential for personalized medicine. Gastroenterology 2008;134:1224-37. [PubMed: 18395100]

167. Jaszewski R, Misra S, Tobi M, et al. Folic acid supplementation inhibits recurrence of colorectal adenomas: a randomized chemoprevention trial. World J Gastroenterol 2008;14:4492-8. [PubMed: 18680228]

168. Cole BF, Baron JA, Sandler RS, et al. Folic acid for the prevention of colorectal adenomas: a randomized clinical trial. JAMA 2007;297:2351-9. [PubMed: 17551129]

169. Paspatis GA, Karamanolis DG. Folate supplementation and adenomatous colonic polyps. Dis Colon Rectum 1994;37:1340-1.

170. Wu K, Platz EA, Willett WC, et al. A randomized trial on folic acid supplementation and risk of recurrent colorectal adenoma. Am J Clin Nutr 2009;90:1623-31. [PubMed: 19864409] 
171. Carroll C, Cooper K, Papaioannou D, et al. Meta-analysis: folic acid in the chemoprevention of colorectal adenomas and colorectal cancer. Aliment Pharmacol Ther 2010;31:708-18. [PubMed: 20085565]

172. Qin T, Du M, Du H, et al. Folic acid supplements and colorectal cancer risk: meta-analysis of randomized controlled trials. Sci Rep 2015;5:12044. [PubMed: 26131763]

173. Moazzen S, Dolatkhah R, Tabrizi JS, et al. Folic acid intake and folate status and colorectal cancer risk: A systematic review and meta-analysis. Clin Nutr 2018;37:1926-1934. [PubMed: 29132834]

174. Sharp L, Little J. Polymorphisms in genes involved in folate metabolism and colorectal neoplasia: a HuGE review. Am J Epidemiol 2004;159:423-43. [PubMed: 14977639]

175. Pence BC. Role of calcium in colon cancer prevention: experimental and clinical studies. Mutat Res 1993;290:87-95. [PubMed: 7694103]

176. Feldman D, Krishnan AV, Swami S, et al. The role of vitamin D in reducing cancer risk and progression. Nat Rev Cancer 2014;14:342-57. [PubMed: 24705652]

177. Harris DM, Go VL. Vitamin D and colon carcinogenesis. J Nutr 2004;134:3463S-3471S. [PubMed: 15570055]

178. Pence BC, Buddingh F. Inhibition of dietary fat-promoted colon carcinogenesis in rats by supplemental calcium or vitamin D3. Carcinogenesis 1988;9:187-90. [PubMed: 2826033]

179. Sheinin Y, Kallay E, Wrba F, et al. Immunocytochemical localization of the extracellular calciumsensing receptor in normal and malignant human large intestinal mucosa. J Histochem Cytochem 2000;48:595-602. [PubMed: 10769043]

180. Baron JA, Barry EL, Mott LA, et al. A Trial of Calcium and Vitamin D for the Prevention of Colorectal Adenomas. N Engl J Med 2015;373:1519-30. [PubMed: 26465985]

181. Leyssens C, Verlinden L, Verstuyf A. Antineoplastic effects of 1,25(OH)2D3 and its analogs in breast, prostate and colorectal cancer. Endocr Relat Cancer 2013;20:R31-47. [PubMed: 23319494]

182. McCullough ML, Robertson AS, Rodriguez C, et al. Calcium, vitamin D, dairy products, and risk of colorectal cancer in the Cancer Prevention Study II Nutrition Cohort (United States). Cancer Causes Control 2003;14:1-12. [PubMed: 12708719]

183. Terry P, Baron JA, Bergkvist L, et al. Dietary calcium and vitamin D intake and risk of colorectal cancer: a prospective cohort study in women. Nutr Cancer 2002;43:39-46. [PubMed: 12467133]

184. Ma Y, Zhang P, Wang F, et al. Association between vitamin D and risk of colorectal cancer: a systematic review of prospective studies. J Clin Oncol 2011;29:3775-82. [PubMed: 21876081]

185. Wu K, Willett WC, Fuchs CS, et al. Calcium intake and risk of colon cancer in women and men. J Natl Cancer Inst 2002;94:437-46. [PubMed: 11904316]

186. Zheng W, Anderson KE, Kushi LH, et al. A prospective cohort study of intake of calcium, vitamin $\mathrm{D}$, and other micronutrients in relation to incidence of rectal cancer among postmenopausal women. Cancer Epidemiol Biomarkers Prev 1998;7:221-5. [PubMed: 9521437]

187. Baron JA, Beach M, Mandel JS, et al. Calcium supplements for the prevention of colorectal adenomas. Calcium Polyp Prevention Study Group. N Engl J Med 1999;340:101-7. [PubMed: 9887161]

188. Wactawski-Wende J, Kotchen JM, Anderson GL, et al. Calcium plus vitamin D supplementation and the risk of colorectal cancer. N Engl J Med 2006;354:684-96. [PubMed: 16481636]

189. Calderwood AH, Baron JA, Mott LA, et al. No Evidence for Posttreatment Effects of Vitamin D and Calcium Supplementation on Risk of Colorectal Adenomas in a Randomized Trial. Cancer Prev Res (Phila) 2019.

190. Crockett SD, Barry EL, Mott LA, et al. Calcium and vitamin D supplementation and increased risk of serrated polyps: results from a randomised clinical trial. Gut 2018.

191. Moyer VA, US Preventive Services Task Force. Vitamin, mineral, and multivitamin supplements for the primary prevention of cardiovascular disease and cancer: U.S. Preventive services Task Force recommendation statement. Ann Intern Med 2014;160:558-64. [PubMed: 24566474]

192. Manson JE, Cook NR, Lee IM, et al. Vitamin D Supplements and Prevention of Cancer and Cardiovascular Disease. N Engl J Med 2019;380:33-44. [PubMed: 30415629] 
193. Barry EL, Peacock JL, Rees JR, et al. Vitamin D Receptor Genotype, Vitamin D3 Supplementation, and Risk of Colorectal Adenomas: A Randomized Clinical Trial. JAMA Oncol 2017;3:628-635. [PubMed: 27978548]

194. Rozhin J, Wilson PS, Bull AW, et al. Ornithine decarboxylase activity in the rat and human colon. Cancer Res 1984;44:3226-30. [PubMed: 6430547]

195. Meyskens FL Jr., McLaren CE, Pelot D, et al. Difluoromethylornithine plus sulindac for the prevention of sporadic colorectal adenomas: a randomized placebo-controlled, double-blind trial. Cancer Prev Res (Phila) 2008;1:32-8. [PubMed: 18841250]

196. Lynch PM, Burke CA, Phillips R, et al. An international randomised trial of celecoxib versus celecoxib plus difluoromethylornithine in patients with familial adenomatous polyposis. Gut 2016;65:286-95. [PubMed: 25792707]

197. Burke CA, Dekker E, Samadder NJ, et al. Efficacy and safety of eflornithine (CPP-1X)/sulindac combination therapy versus each as monotherapy in patients with familial adenomatous polyposis (FAP): design and rationale of a randomized, double-blind, Phase III trial. BMC Gastroenterol 2016;16:87. [PubMed: 27480131]

198. Eisinger AL, Nadauld LD, Shelton DN, et al. The adenomatous polyposis coli tumor suppressor gene regulates expression of cyclooxygenase- 2 by a mechanism that involves retinoic acid. J Biol Chem 2006;281:20474-82. [PubMed: 16699180]

199. Coffey RJ, Hawkey CJ, Damstrup L, et al. Epidermal growth factor receptor activation induces nuclear targeting of cyclooxygenase-2, basolateral release of prostaglandins, and mitogenesis in polarizing colon cancer cells. Proc Natl Acad Sci U S A 1997;94:657-62. [PubMed: 9012840]

200. Samadder NJ, Neklason DW, Boucher KM, et al. Effect of Sulindac and Erlotinib vs Placebo on Duodenal Neoplasia in Familial Adenomatous Polyposis: A Randomized Clinical Trial. JAMA 2016;315:1266-75. [PubMed: 27002448]

201. Samadder NJ, Kuwada SK, Boucher KM, et al. Association of Sulindac and Erlotinib vs Placebo With Colorectal Neoplasia in Familial Adenomatous Polyposis: Secondary Analysis of a Randomized Clinical Trial. JAMA Oncol 2018;4:671-677. [PubMed: 29423501]

202. Cruz-Correa M, Hylind LM, Marrero JH, et al. Efficacy and Safety of Curcumin in Treatment of Intestinal Adenomas in Patients With Familial Adenomatous Polyposis. Gastroenterology 2018;155:668-673. [PubMed: 29802852]

203. Langowski JL, Zhang X, Wu L, et al. IL-23 promotes tumour incidence and growth. Nature 2006;442:461-5. [PubMed: 16688182]

204. Grivennikov SI, Wang K, Mucida D, et al. Adenoma-linked barrier defects and microbial products drive IL-23/IL-17-mediated tumour growth. Nature 2012;491:254-8. [PubMed: 23034650]

205. Lan F, Zhang L, Wu J, et al. IL-23/IL-23R: potential mediator of intestinal tumor progression from adenomatous polyps to colorectal carcinoma. Int J Colorectal Dis 2011;26:1511-8. [PubMed: 21547355]

206. A study of Guselkumab in Participants with Familial Adenomatous Polyposis. ClinicalTrials.gov, NCT03649971. Accessible at: https://clinicaltrials.gov/ct2/show/NCT03649971? id=03649971\&rank=1.

207. Elsheikh W, Blackler RW, Flannigan KL, et al. Enhanced chemopreventive effects of a hydrogen sulfide-releasing anti-inflammatory drug (ATB-346) in experimental colorectal cancer. Nitric Oxide 2014;41:131-7. [PubMed: 24747869]

208. Paul-Clark M, Elsheikh W, Kirkby N, et al. Profound Chemopreventative Effects of a Hydrogen Sulfide-Releasing NSAID in the APCMin/+ Mouse Model of Intestinal Tumorigenesis. PLoS One 2016;11:e0147289. [PubMed: 26910063]

209. Chattopadhyay M, Kodela R, Duvalsaint PL, et al. Gastrointestinal safety, chemotherapeutic potential, and classic pharmacological profile of NOSH-naproxen (AVT-219) a dual NO- and H2S-releasing hybrid. Pharmacol Res Perspect 2016;4:e00224. [PubMed: 27069635]

210. Niles RM. Vitamin A and cancer. Nutrition 2000;16:573-6. [PubMed: 10906560]

211. Semba RD. Vitamin A and immunity to viral, bacterial and protozoan infections. Proc Nutr Soc 1999;58:719-27. [PubMed: 10604208]

212. Padayatty SJ, Katz A, Wang Y, et al. Vitamin C as an antioxidant: evaluation of its role in disease prevention. J Am Coll Nutr 2003;22:18-35. [PubMed: 12569111] 
213. Packer L. Protective role of vitamin E in biological systems. Am J Clin Nutr 1991;53:1050S1055S. [PubMed: 2012017]

214. Kline K, Yu W, Sanders BG. Vitamin E: mechanisms of action as tumor cell growth inhibitors. J Nutr 2001;131:161S-163S. [PubMed: 11208955]

215. Young AJ, Lowe GM. Antioxidant and prooxidant properties of carotenoids. Arch Biochem Biophys 2001;385:20-7. [PubMed: 11361018]

216. Omenn GS, Goodman G, Thornquist M, et al. The beta-carotene and retinol efficacy trial (CARET) for chemoprevention of lung cancer in high risk populations: smokers and asbestosexposed workers. Cancer Res 1994;54:2038s-2043s. [PubMed: 8137335]

217. Alpha-Tocopherol, Beta Carotene Cancer Prevention Study Group. The effect of vitamin E and beta carotene on the incidence of lung cancer and other cancers in male smokers. N Engl J Med 1994;330:1029-35. [PubMed: 8127329]

218. Davis CD, Tsuji PA, Milner JA. Selenoproteins and cancer prevention. Annu Rev Nutr 2012;32:73-95. [PubMed: 22404120]

219. Jurutka PW, Whitfield GK, Hsieh JC, et al. Molecular nature of the vitamin D receptor and its role in regulation of gene expression. Rev Endocr Metab Disord 2001;2:203-16. [PubMed: 11705326]

220. Lin JK. Molecular targets of curcumin. Adv Exp Med Biol 2007;595:227-43. [PubMed: 17569214] 

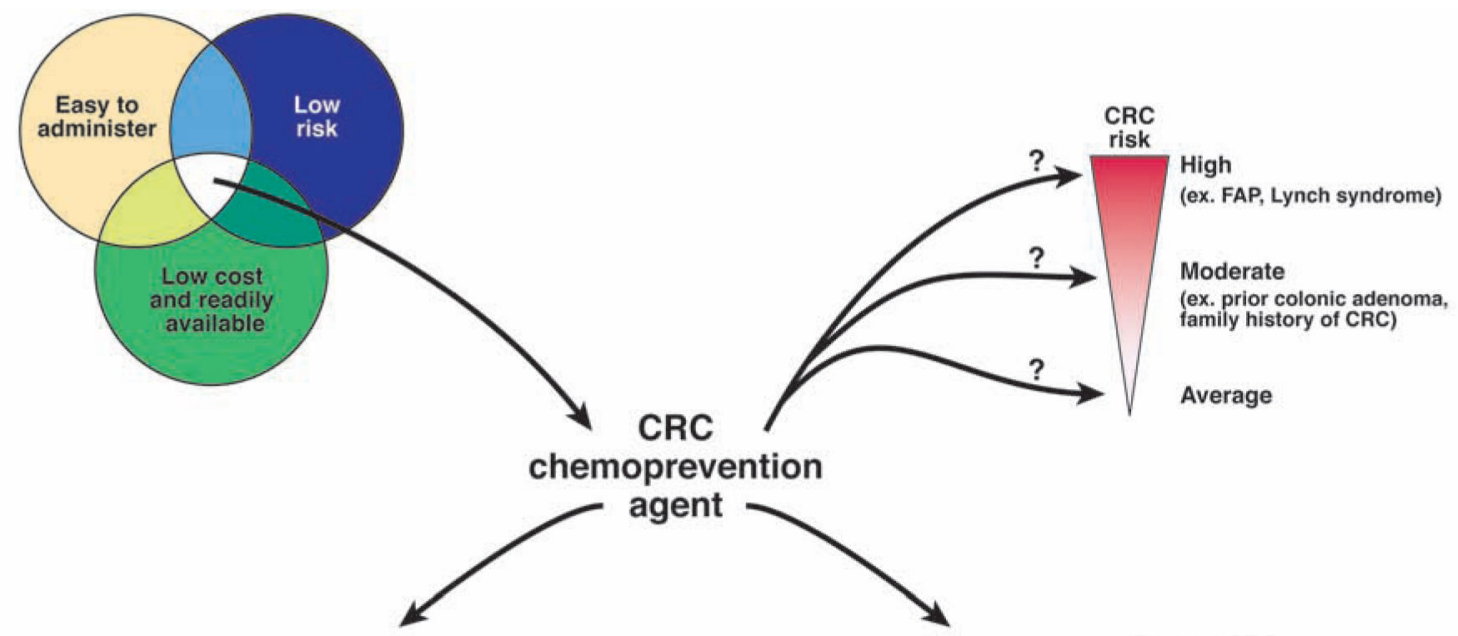

$\begin{array}{cc}\text { Prevent } & \text { Prevent neoplastic } \\ \text { adenoma } & \text { transformation of }\end{array}$

$\begin{array}{rr}\text { adenoma } & \text { transformation } \\ \text { formation } & \text { an adenoma }\end{array}$
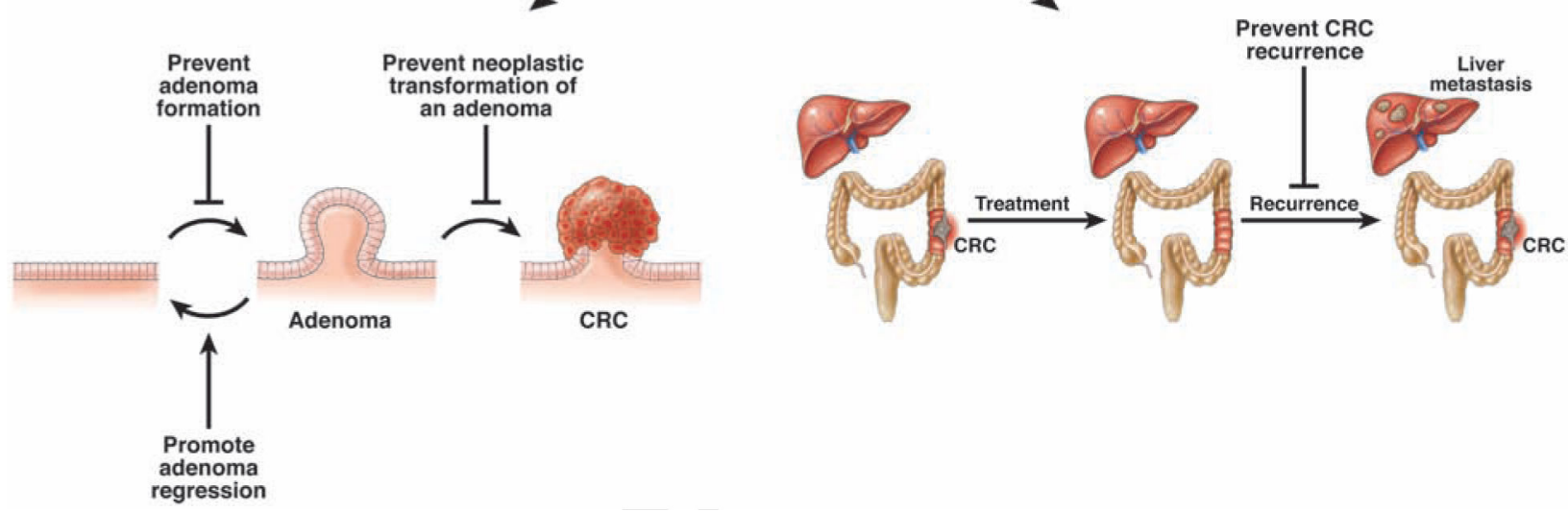

Figure 1.

Complexities of CRC chemoprevention. There are many factors to consider in evaluating CRC chemoprevention agents, including the intrinsic properties of the agent (side effects, cost, ease of administration), mechanisms of chemoprevention, and groups most likely to benefit with the least risk. 


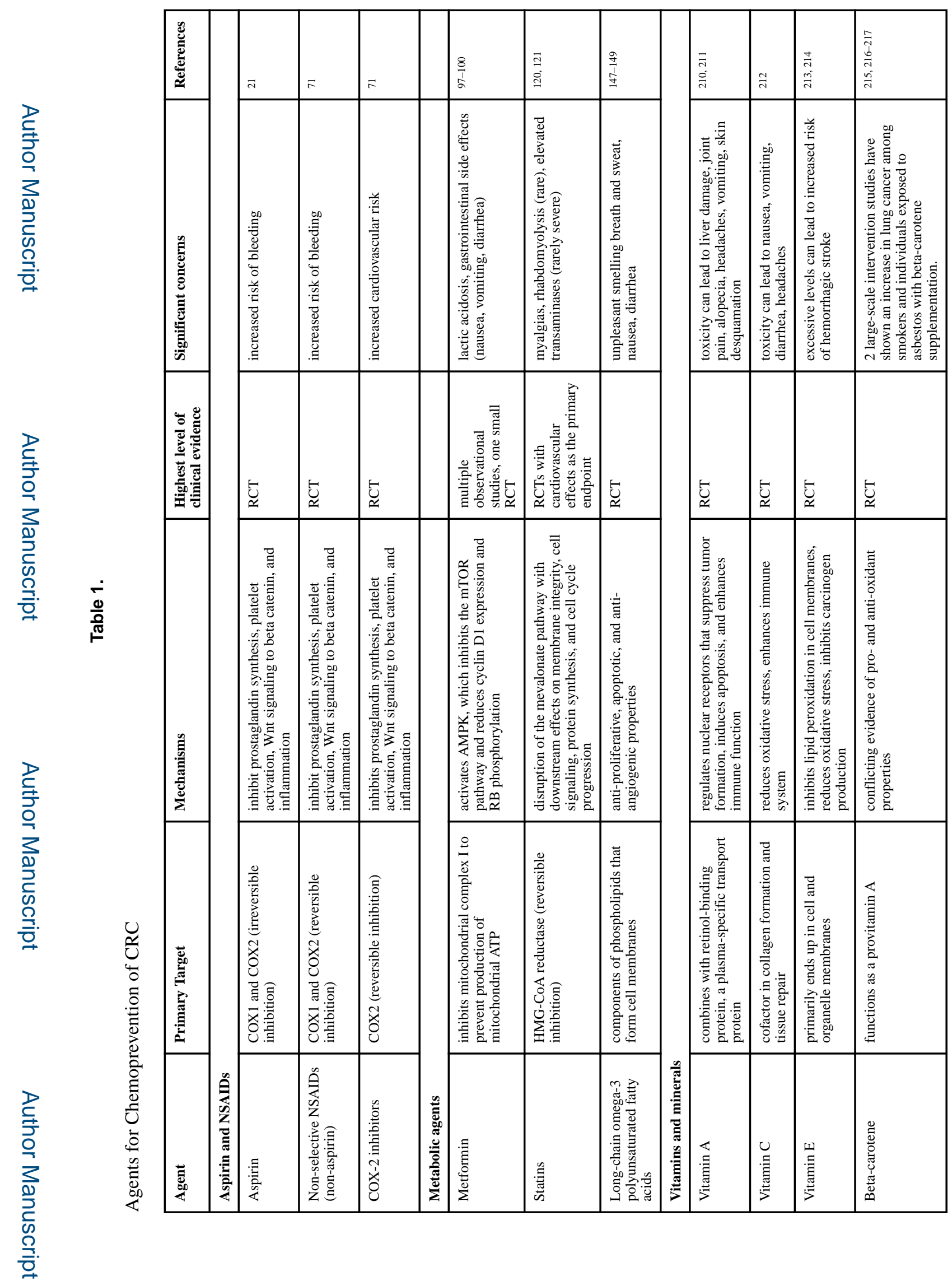

Gastroenterology. Author manuscript; available in PMC 2021 January 01. 


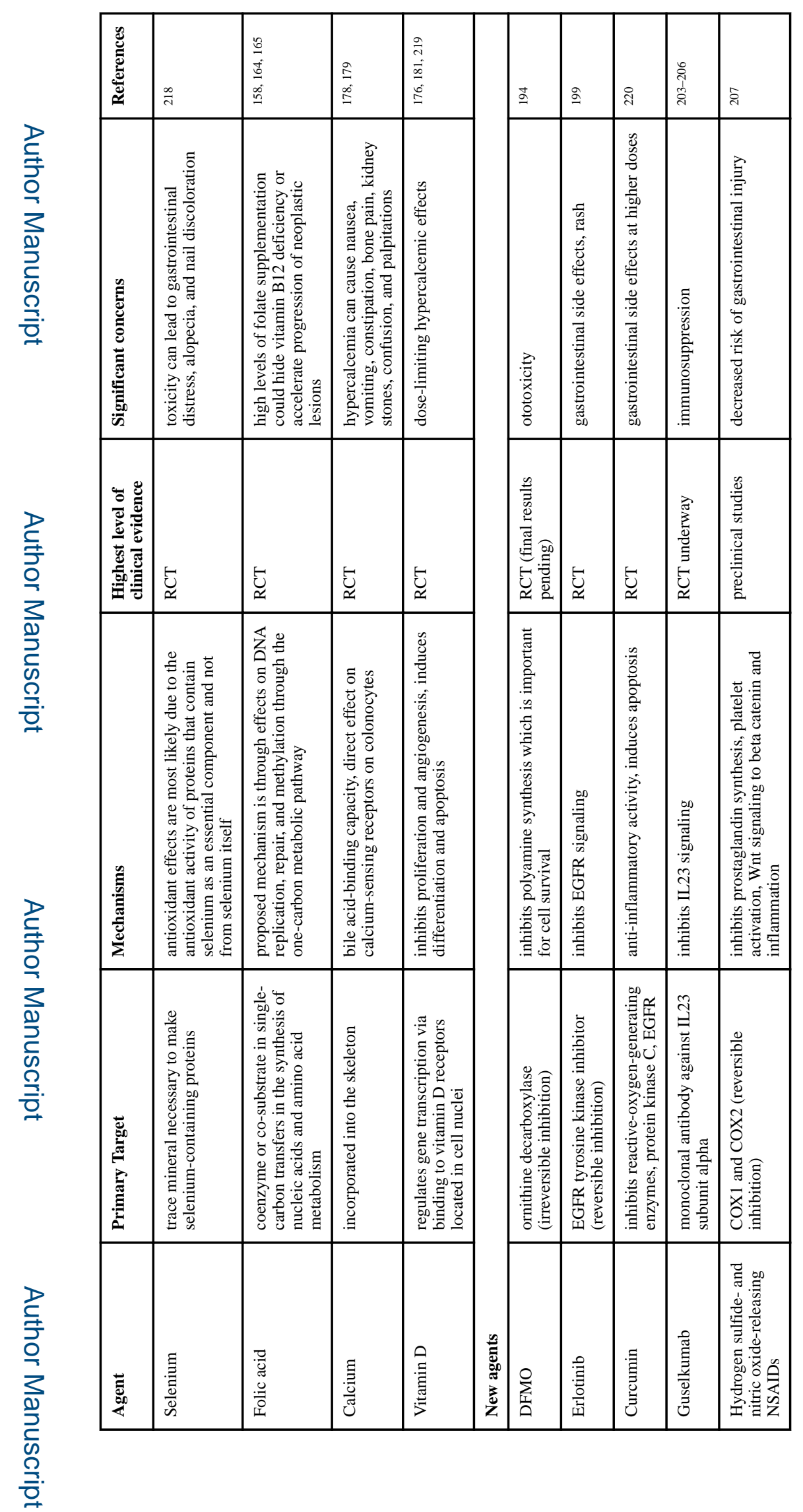

Gastroenterology. Author manuscript; available in PMC 2021 January 01. 


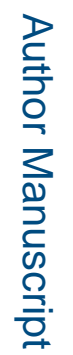

\begin{tabular}{|c|c|c|c|c|c|c|c|c|c|c|}
\hline 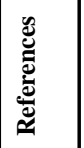 & & $\infty$ & $\infty$ & $\begin{array}{l}f \\
\vec{f} \\
\vec{f}\end{array}$ & iे & m & $\mid \begin{array}{l}\text { ?] } \\
\text { ह }\end{array}$ & 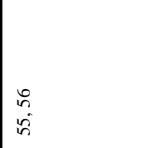 & 8 & \\
\hline 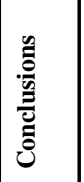 & & 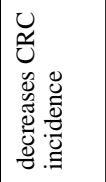 & 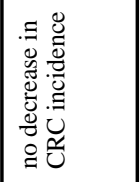 & 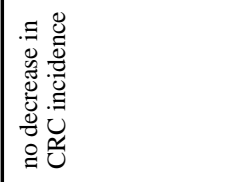 & 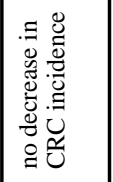 & 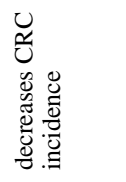 & 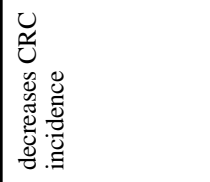 & 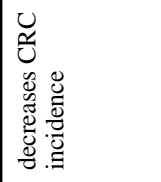 & 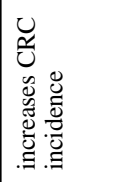 & \\
\hline 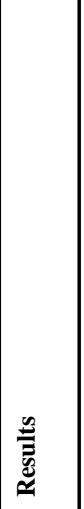 & & 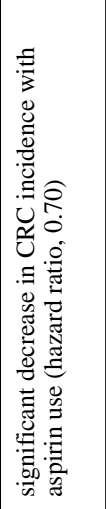 & 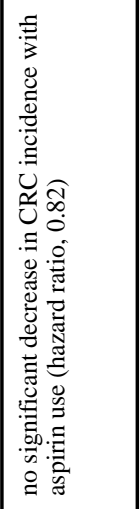 & 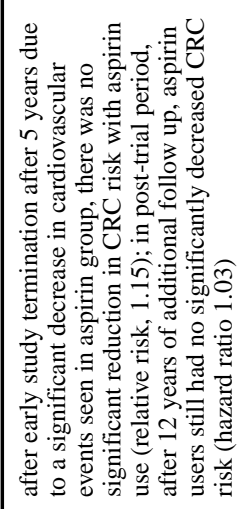 & 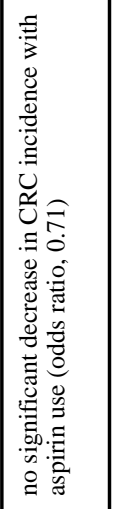 & 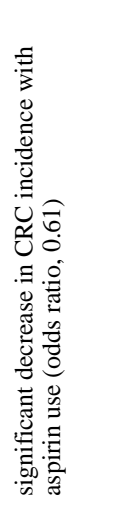 & 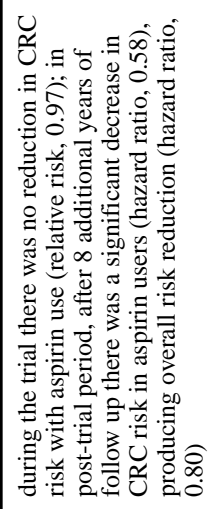 & 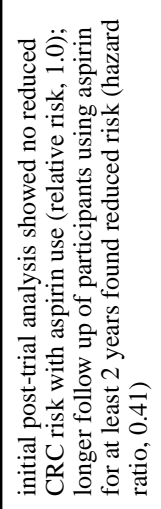 & 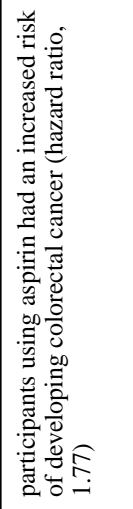 & \\
\hline 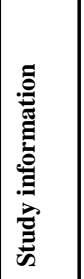 & & 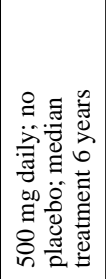 & 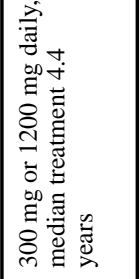 & 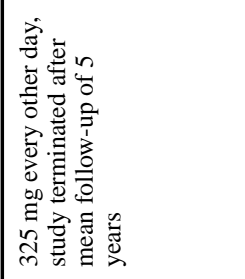 & 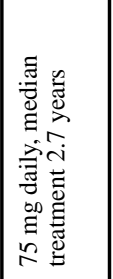 & 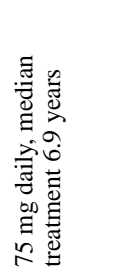 & 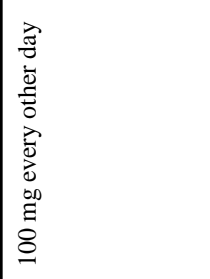 & 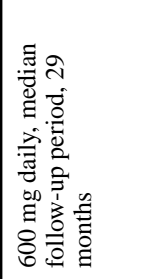 & 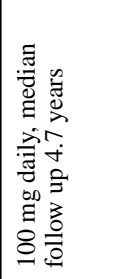 & \\
\hline 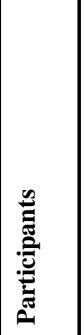 & & 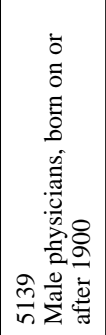 & 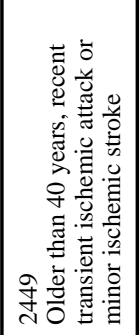 & 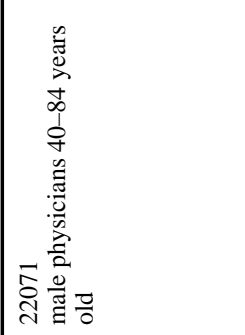 & 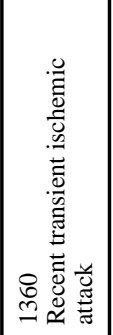 & 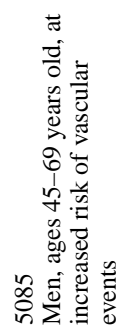 & 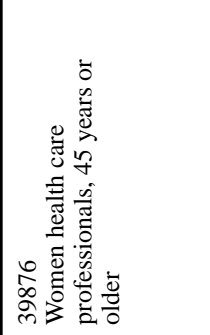 & 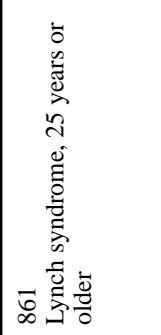 & 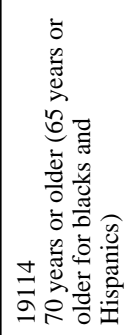 & \\
\hline 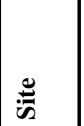 & & 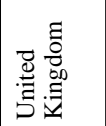 & 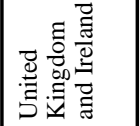 & $\tilde{s}$ & 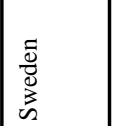 & 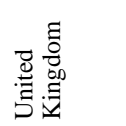 & $\tilde{s}$ & 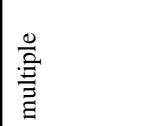 & 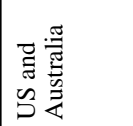 & \\
\hline 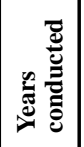 & & $\begin{array}{l}+ \\
2 \\
2 \\
1 \\
\infty \\
\vdots \\
2\end{array}$ & $\begin{array}{l}0 \\
2 \\
2 \\
\vdots \\
\vdots \\
\vdots \\
\vdots\end{array}$ & 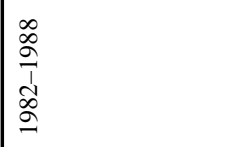 & 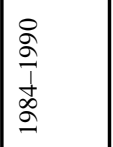 & $\begin{array}{l}\hat{a} \\
\frac{1}{1} \\
\text { oे } \\
2\end{array}$ & 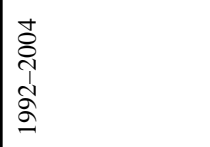 & 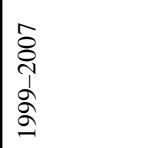 & 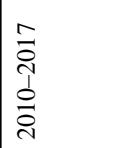 & \\
\hline 荵 & 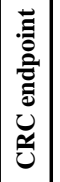 & 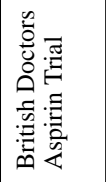 & 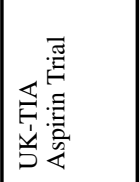 & 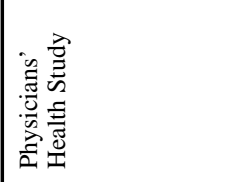 & 空 & 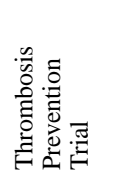 & 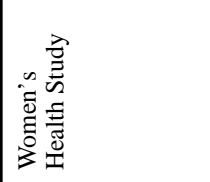 & 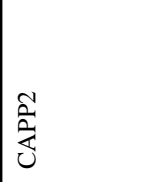 & $\begin{array}{l}\text { 画 } \\
\frac{2}{2} \\
\frac{2}{4} \\
\frac{2}{4}\end{array}$ & 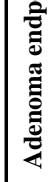 \\
\hline
\end{tabular}

Gastroenterology. Author manuscript; available in PMC 2021 January 01. 


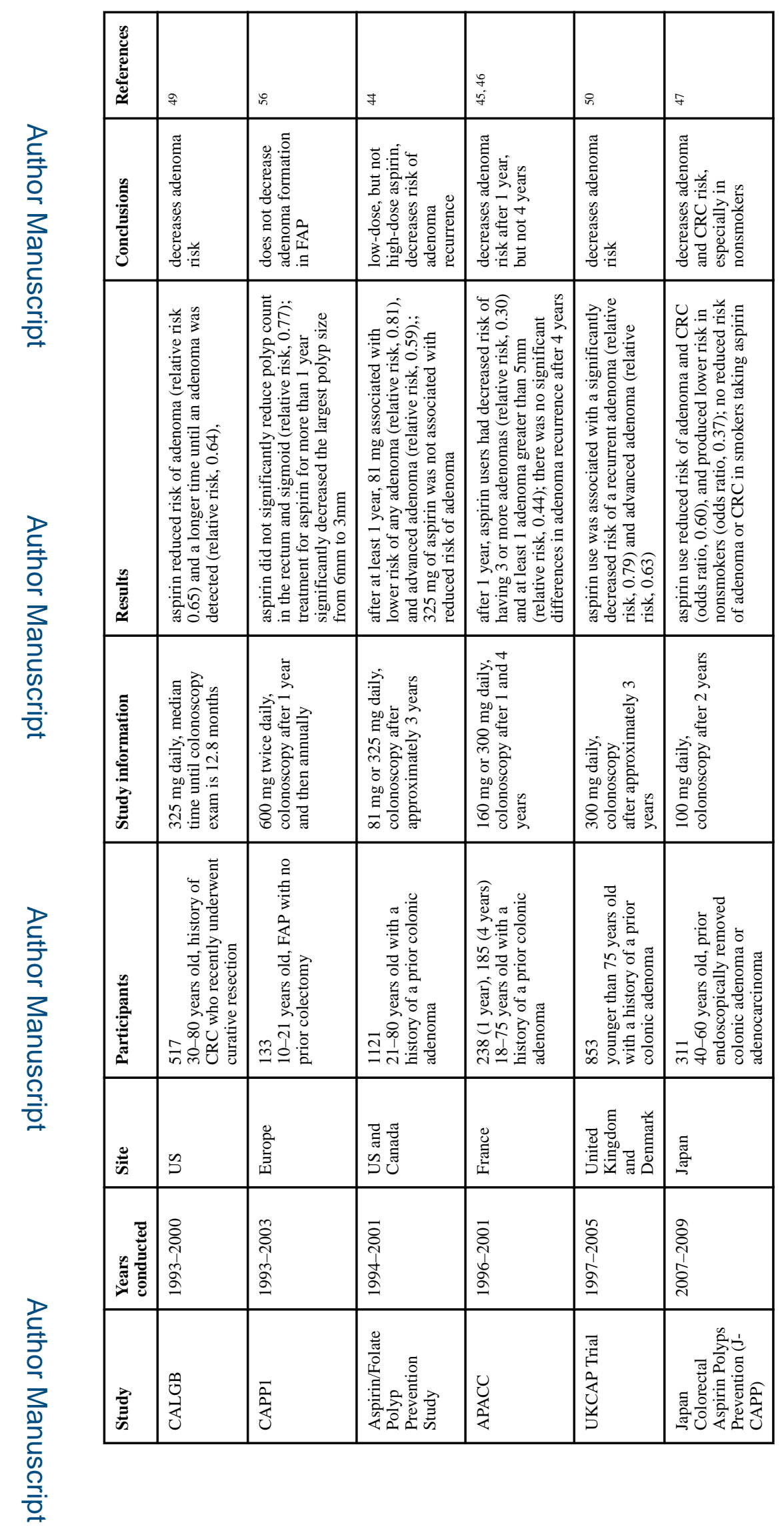

Gastroenterology. Author manuscript; available in PMC 2021 January 01. 


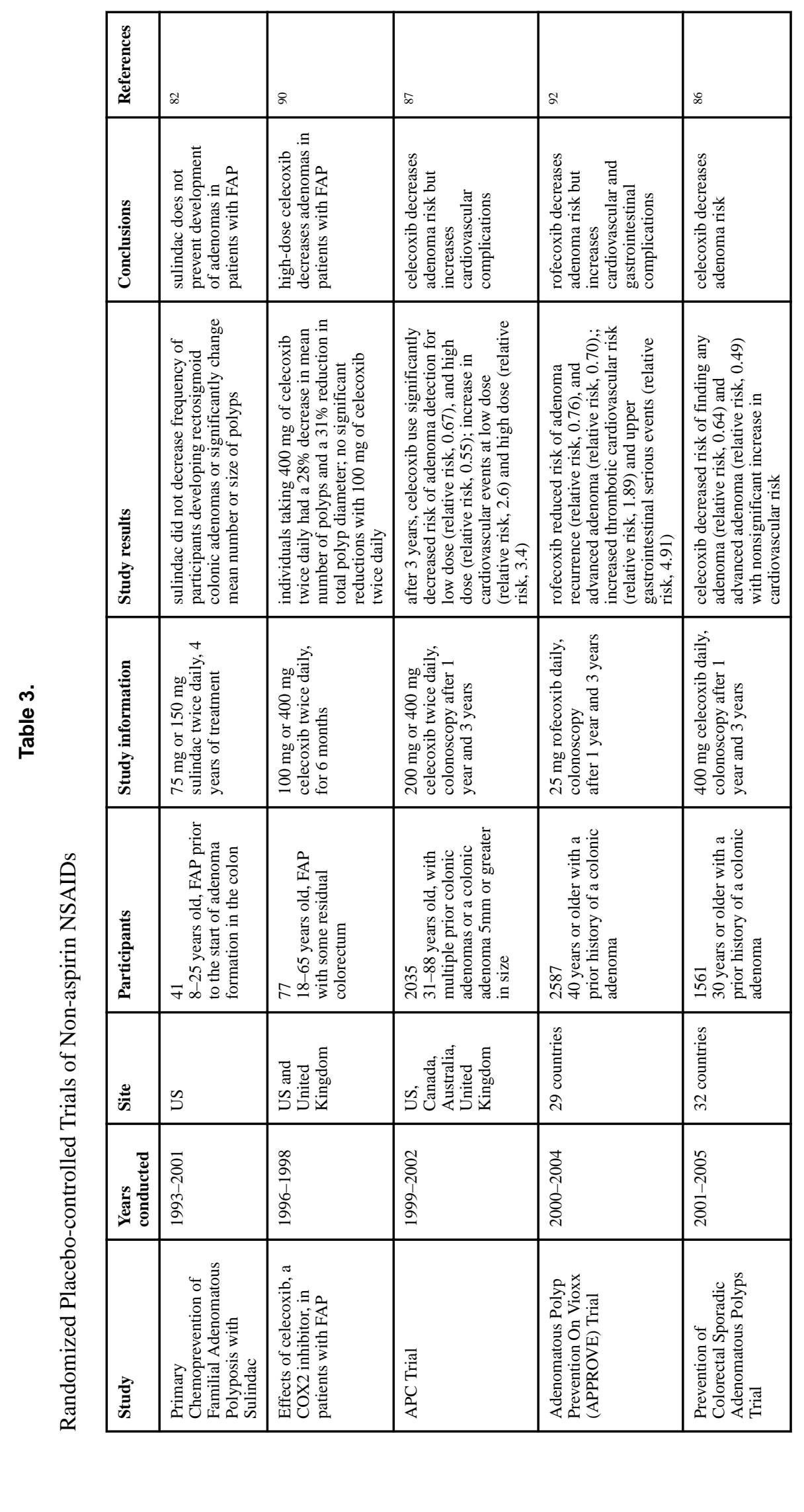

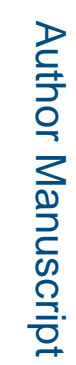

Gastroenterology. Author manuscript; available in PMC 2021 January 01. 